\title{
Climatic effects of 1950-2050 changes in US anthropogenic aerosols - Part 1: Aerosol trends and radiative forcing
}

\author{
E. M. Leibensperger ${ }^{1, *}$, L. J. Mickley ${ }^{1}$, D. J. Jacob ${ }^{1}$, W.-T. Chen ${ }^{2}$, J. H. Seinfeld ${ }^{3}$, A. Nenes ${ }^{4}$, P. J. Adams ${ }^{5}$, \\ D. G. Streets ${ }^{6}$, N. Kumar ${ }^{7}$, and D. Rind ${ }^{8}$ \\ ${ }^{1}$ School of Engineering and Applied Sciences, Harvard University, Cambridge, MA, USA \\ ${ }^{2}$ Jet Propulsion Laboratory, California Institute of Technology, Pasadena, CA, USA \\ ${ }^{3}$ Division of Chemistry and Chemical Engineering, California Institute of Technology, Pasadena, CA, USA \\ ${ }^{4}$ School of Earth \& Atmospheric Sciences and School of Chemical \& Biological Engineering, Georgia Institute of \\ Technology, Atlanta, GA, USA \\ ${ }^{5}$ Department of Civil \& Environmental Engineering and Department of Engineering \& Public Policy, Carnegie Mellon \\ University, Pittsburgh, PA, USA \\ ${ }^{6}$ Argonne National Laboratory, Argonne, IL, USA \\ ${ }^{7}$ Electric Power Research Institute, Palo Alto, CA, USA \\ ${ }^{8}$ NASA Goddard Institute for Space Studies, New York, NY, USA \\ *now at: Department of Earth, Atmospheric and Planetary Sciences, Massachusetts Institute of Technology, \\ Cambridge, MA, USA
}

Correspondence to: E. M. Leibensperger (eleibens@mit.edu)

Received: 20 May 2011 - Published in Atmos. Chem. Phys. Discuss.: 29 August 2011

Revised: 21 March 2012 - Accepted: 29 March 2012 - Published: 10 April 2012

\begin{abstract}
We calculate decadal aerosol direct and indirect (warm cloud) radiative forcings from US anthropogenic sources over the 1950-2050 period. Past and future aerosol distributions are constructed using GEOS-Chem and historical emission inventories and future projections from the IPCC A1B scenario. Aerosol simulations are evaluated with observed spatial distributions and 1980-2010 trends of aerosol concentrations and wet deposition in the contiguous US. Direct and indirect radiative forcing is calculated using the GISS general circulation model and monthly mean aerosol distributions from GEOS-Chem. The radiative forcing from US anthropogenic aerosols is strongly localized over the eastern US. We find that its magnitude peaked in 1970-1990, with values over the eastern US (east of $100^{\circ} \mathrm{W}$ ) of $-2.0 \mathrm{~W} \mathrm{~m}^{-2}$ for direct forcing including contributions from sulfate $\left(-2.0 \mathrm{~W} \mathrm{~m}^{-2}\right)$, nitrate $\left(-0.2 \mathrm{~W} \mathrm{~m}^{-2}\right)$, organic carbon $\left(-0.2 \mathrm{~W} \mathrm{~m}^{-2}\right)$, and black carbon $\left(+0.4 \mathrm{~W} \mathrm{~m}^{-2}\right)$. The uncertainties in radiative forcing due to aerosol radiative properties are estimated to be about $50 \%$. The aerosol indirect effect is estimated to be of comparable magnitude to the direct forcing. We find that the magnitude of the forc-
\end{abstract}

ing declined sharply from 1990 to 2010 (by $0.8 \mathrm{~W} \mathrm{~m}^{-2}$ direct and $1.0 \mathrm{~W} \mathrm{~m}^{-2}$ indirect), mainly reflecting decreases in $\mathrm{SO}_{2}$ emissions, and project that it will continue declining post-2010 but at a much slower rate since US $\mathrm{SO}_{2}$ emissions have already declined by almost $60 \%$ from their peak. This suggests that much of the warming effect of reducing US anthropogenic aerosol sources has already been realized. The small positive radiative forcing from US BC emissions $\left(+0.3 \mathrm{~W} \mathrm{~m}^{-2}\right.$ over the eastern US in $2010 ; 5 \%$ of the global forcing from anthropogenic BC emissions worldwide) suggests that a US emission control strategy focused on BC would have only limited climate benefit.

\section{Introduction}

Growth in population and energy demand over the past $100 \mathrm{yr}$ has greatly increased the anthropogenic source of atmospheric aerosols in the United States. This has caused public health, visibility, and deposition concerns (US Environmental Protection Agency (US EPA), 2009, 2010). 
Increasingly strict regulations on aerosol sources have been enacted by US air quality agencies over the past decades. However, aerosols also exert a negative radiative forcing on climate and reductions in their abundance aggravate greenhouse-driven climate change (Raes and Seinfeld, 2009). We quantify in this paper the changes in radiative forcing arising from historical and projected trends of US anthropogenic aerosol sources for the 1950-2050 period. In a companion paper (Leibensperger et al., 2012), we use a general circulation model (GCM) to analyze the resulting climate response.

Anthropogenic aerosols mainly consist of sulfate, nitrate, ammonium, black carbon (BC), and organic carbon (OC). Sulfate and nitrate aerosols are formed by oxidation of $\mathrm{SO}_{2}$ and nitrogen oxides $\left(\mathrm{NO}_{\mathrm{x}} \equiv \mathrm{NO}+\mathrm{NO}_{2}\right)$. Coal combustion is the dominant source of $\mathrm{SO}_{2}$ in the US. $\mathrm{SO}_{2}$ emissions grew until 1980 and then decreased by $56 \%$ between 1980 and 2008 (US EPA, 2010). Anthropogenic $\mathrm{NO}_{\mathrm{x}}$ is emitted by fuel combustion in general and US emissions decreased by $36 \%$ between 1990 and 2008 (US EPA, 2010). Ammonia originates mainly from agriculture (Bouwman et al., 1997) and has not been subjected to regulation. BC is emitted from small, low-temperature combustion sources such as residential, transport, and small industrial fuel burning. Organic aerosol is traditionally partitioned by models into a primary component (POA) from combustion and a secondary component (SOA) of dominant biogenic origin (Kanakidou et al., 2005). According to Bond et al. (2007), US anthropogenic emissions of BC and POA decreased from 1925 to 1970 due to a decline in residential coal use, but increased from 1970 to 1990 due to increases in broader fuel use.

Aerosols directly affect climate by scattering and absorbing solar radiation. The Intergovernmental Panel on Climate Change (IPCC) estimates the aerosol direct effect to presently exert a global mean negative radiative forcing of $-0.5 \pm 0.4 \mathrm{~W} \mathrm{~m}^{-2}$, partly offsetting the positive radiative forcing of $+2.6 \pm 0.3 \mathrm{~W} \mathrm{~m}^{-2}$ from the long-lived greenhouse gases (Forster et al., 2007). Aerosols also indirectly affect climate by modifying cloud properties. Absorbing aerosols affect cloud cover by increasing solar heating in the atmosphere ("semi-direct effect"; Koch and Del Genio, 2010). Aerosols can also act as cloud condensation nuclei $(\mathrm{CCN})$ and ice nuclei. An increase in $\mathrm{CCN}$ reduces cloud droplet size, which brightens the clouds ("cloud albedo effect"; Twomey, 1974) and enhances cloud cover by reducing precipitation efficiency ("cloud lifetime effect"; Albrecht, 1989). The IPCC best estimate for the global indirect radiative forcing from the cloud albedo effect is $-0.7 \mathrm{~W} \mathrm{~m}^{-2}$, with a range of uncertainty from -0.3 to $-1.8 \mathrm{~W} \mathrm{~m}^{-2}$ (Forster et al., 2007). The cloud lifetime effect is even more uncertain, but could be comparable in magnitude to the cloud albedo effect with additional effects on the hydrological cycle (Lohmann and Feichter, 2005; Denman et al., 2007). Additional aerosol indirect radiative effects involving cloud ab- sorption, height, or glaciation could also be significant (Denman et al., 2007).

The need to integrate air quality and climate change mitigation objectives in environmental policymaking is increasingly recognized (National Research Council, 2005; Raes and Seinfeld, 2009; Penner et al., 2010). This is particularly the case for aerosols since air quality improvements potentially come at the cost of warming. Previous studies have investigated the climate effects of global aerosol sources (Shindell et al., 2008; Chen et al., 2010b; Koch et al., 2011), but understanding the effects of national sources is most useful for policymakers. The US is an interesting testbed to analyze the climate implications of environmental regulations since the historical period from 1950 to present has witnessed a reversal of aerosol trends, increasing until 1980 and then decreasing, with regulations in place to enforce continued decrease in the future. Recent GCM simulations by Mickley et al. (2012) suggest that completely removing US anthropogenic aerosol sources would increase temperatures in the eastern US by $0.4-0.6^{\circ} \mathrm{C}$ on an annual mean basis and as much as by $1-2^{\circ} \mathrm{C}$ during summer heat waves.

Unlike other aerosol components, $\mathrm{BC}$ exerts a positive direct radiative forcing on climate. It has been argued that decreasing BC emissions (and hence aerosol absorption) could provide a "win-win" strategy for air quality and climate change mitigation (Jacobson, 2002; Bond, 2007; Grieshop et al., 2009). However, such a strategy is complicated by the fact that BC sources cannot be controlled in isolation from other aerosol components, in particular POA (Unger et al., 2010). There is additional uncertainty regarding the sign of the semi-direct and indirect effects associated with BC (Koch and Del Genio, 2010; Koch et al., 2011; Chen et al., 2010a).

We use here a global chemical transport model (GEOSChem CTM) to reconstruct historical aerosol trends from 1950 to present and project future trends to 2050, with focus on the US aerosol loadings and evaluation with observed trends. We then use these monthly mean aerosol distributions as input to the Goddard Institute for Space Studies (GISS) GCM 3 to construct a 1950-2050 timeline of aerosol direct and indirect radiative forcing with decadal resolution, resolving the contributions from the different aerosol components. The aerosol distributions presented here are used in a companion paper (Leibensperger et al., 2012) to determine the sensitivity of US climate to anthropogenic aerosol sources in the past and in the future.

\section{Methods}

\subsection{Global aerosol simulation}

We use GEOS-Chem CTM simulations of coupled tropospheric ozone- $\mathrm{NO}_{\mathrm{x}}-\mathrm{VOC}$-aerosol chemistry (version 8.01.01; http://geos-chem.org/) to describe the global evolution of aerosol concentrations resulting from changes in 
anthropogenic emissions from 1950 to 2050 . The simulations are conducted for a series of 2 -yr decadal time slices from 1950 to 2050. The first year is used for initialization and the second year for analysis. All simulations use the same 2000-2001 meteorological data from the NASA Goddard Earth Observing System (GEOS-4). The GEOS-4 data are available with $1 \times 1.25^{\circ}$ horizontal resolution, 55 levels in the vertical, and a temporal resolution of $6 \mathrm{~h}$ ( $3 \mathrm{~h}$ for surface variables). The data are regridded here to $2 \times 2.5^{\circ}$ horizontal resolution for input to GEOS-Chem. Using the same meteorological year for the 1950-2050 simulations isolates the effects of emission changes. Climate change over that period might affect monthly mean aerosol concentrations by $\pm 0.1-1 \mu \mathrm{g} \mathrm{m}^{-3}$, with even the sign of the effect uncertain (Jacob and Winner, 2009). Aerosol abundances are more sensitive to the large emission changes simulated here.

GEOS-Chem simulates the aerosol mass concentrations of sulfate-nitrate-ammonium (SNA), POA, SOA, BC, and sizeresolved sea salt and soil dust (Park et al., 2006; Liao et al., 2007). Sea salt and soil dust are viewed as natural and are not discussed here further. Gas-phase and aerosol chemistry are coupled by in-cloud $\mathrm{SO}_{2}$ oxidation, gas-aerosol thermodynamic partitioning of SNA and SOA, aerosol effects on photolysis rates (Martin et al., 2003), and heterogeneous chemistry (Jacob, 2000; Evans and Jacob, 2005). Water-soluble gases and aerosols are scavenged in convective updrafts as well as by rainout and washout from convective anvils and large-scale precipitation (Liu et al., 2001). The model allows for species to return to the atmosphere if falling precipitation evaporates. Dry deposition is modeled using a resistance in series scheme (Wesely, 1989) as implemented by Wang et al. (1998).

Sulfate is formed by gas-phase reaction of $\mathrm{SO}_{2}$ with $\mathrm{OH}$ and by aqueous-phase reaction of $\mathrm{SO}_{2}$ with $\mathrm{H}_{2} \mathrm{O}_{2}$ and ozone in clouds and sea-salt aerosols (Alexander et al., 2005). The global mean tropospheric lifetime of sulfate in the model (computed as the ratio of global burden to deposition) is 4.0 days, comparable to other sulfate models (Schulz et al., 2006). Formation of SNA aerosol is computed locally with the MARS-A aerosol thermodynamic equilibrium model (Binkowski and Roselle, 2003). Following Park et al. (2003), we assume that $20 \%$ of $\mathrm{BC}$ and $50 \%$ of POA emitted from anthropogenic sources is hydrophilic and thus available for in-cloud scavenging. The remaining portions of BC and POA are emitted as hydrophobic and become hydrophilic in the atmosphere with an e-folding time of 1.2 days. Formation of SOA in GEOS-Chem involves gas-aerosol partitioning of semi-volatile oxidation products from isoprene and terpenes (Heald et al., 2006; Liao et al., 2007). Global production of SOA is $32 \mathrm{Tg} \mathrm{Ca}^{-1}$, similar in magnitude to previous GEOSChem studies (Henze et al., 2008; Pye et al., 2010).

Figure 1 shows the 1950-2050 trends of global and US aerosol sources. Emissions of $\mathrm{SO}_{2}$ and $\mathrm{NO}_{\mathrm{x}}$ are from EDGAR Hyde 1.3 (van Aardenne et al., 2001) for 1950-
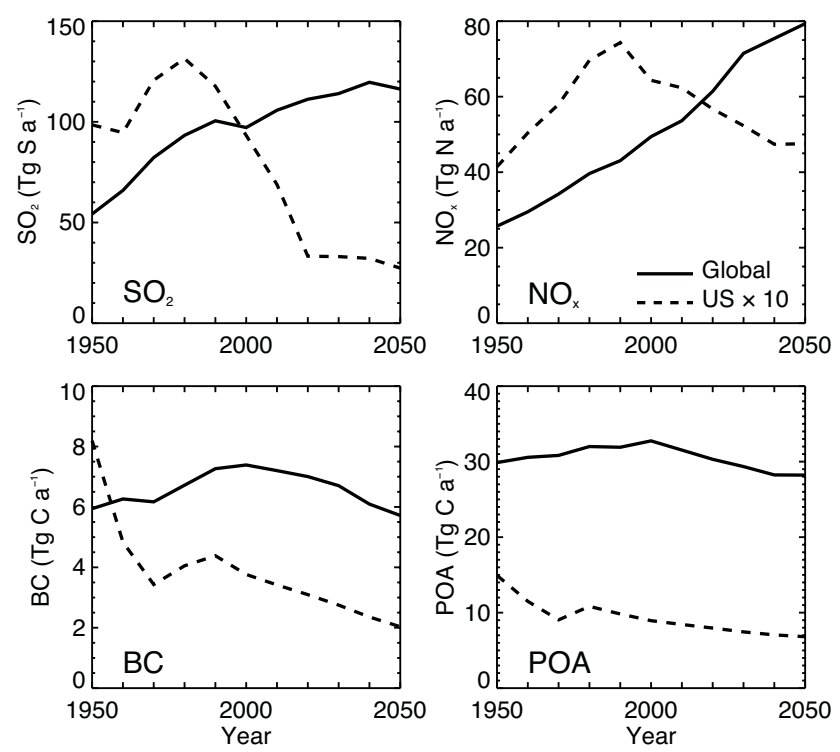

Fig. 1. Global (solid) and US (dashed) trends in emissions of $\mathrm{SO}_{2}$, $\mathrm{NO}_{\mathrm{x}}, \mathrm{BC}$, and POA for 1950-2050. US emissions are multiplied by 10 to fit on scale. $\mathrm{SO}_{2}$ and $\mathrm{NO}_{\mathrm{x}}$ emissions are from EDGAR (van Aardenne et al., 2001; Olivier and Berdowski, 2001). BC and POA emissions are from Bond et al. (2007). All emissions are extended past the year 2000 following the IPCC A1B scenario.

1990 and EDGAR 3.2 FT (Olivier and Berdowski, 2001) for the year 2000. Emissions of BC and POA are from Bond et al. (2007). 2010-2050 decadal emissions are calculated by applying growth factors to year 2000 emissions. Similar to Fiore et al. (2002) and Wu et al. (2008), growth factors for different categories of anthropogenic emissions (biofuel and fossil fuel) and countries are derived from the Integrated Model to Assess the Greenhouse Effect (IMAGE; Streets et al., 2004) following the IPCC A1B scenario (Nakičenovič and Swart, 2000). The decline of US anthropogenic $\mathrm{SO}_{2}$ and $\mathrm{BC}$ in the $\mathrm{A} 1 \mathrm{~B}$ scenario is comparable to those in the more recent RCP6.0 scenario from the IPCC AR5 (Moss et al., 2010). All RCP scenarios decrease global $\mathrm{SO}_{2}, \mathrm{NO}_{\mathrm{x}}$, $\mathrm{BC}$, and POA and US $\mathrm{NO}_{\mathrm{x}}$ emissions more rapidly than the A1B scenario. We do not consider trends in global emissions from aircraft $\left(0.07 \mathrm{Tg} \mathrm{Sa}^{-1}\right.$; Chin et al., 2000) and ships (4.2 $\mathrm{Tg} \mathrm{S} \mathrm{a}^{-1}$; Corbett et al., 1999).

Natural sources of $\mathrm{SO}_{2}, \mathrm{NO}_{\mathrm{x}}$, and VOCs are held constant for the 1950-2050 period. Volcanic emissions of $\mathrm{SO}_{2}$ (noneruptive and continuously eruptive only) are from Andres and Kasgnoc (1998) and amount to $5.5 \mathrm{Tg} \mathrm{S} \mathrm{a}^{-1}$. Oceanic dimethylsulfide (DMS) in GEOS-Chem has a global source of $21 \mathrm{Tg} \mathrm{Sa}^{-1}$ and produces $19 \mathrm{Tg} \mathrm{S} \mathrm{a}^{-1}$ of $\mathrm{SO}_{2}$ following oxidation by $\mathrm{OH}$ and $\mathrm{NO}_{3}$ (Park et al., 2004). Lightning $\mathrm{NO}_{\mathrm{x}}$ emissions are calculated from a parameterization based on cloud top height (Price and Rind, 1992) and then scaled locally to match satellite observations from the Optical Transient Detector/Lightning Imaging Sensor (Sauvage et al., 
2007; Murray et al., 2012). The global emission of lightning $\mathrm{NO}_{\mathrm{x}}$ is $5.6 \mathrm{Tg} \mathrm{Na}^{-1}$. Soil $\mathrm{NO}_{\mathrm{x}}$ emissions follow the algorithm of Yienger and Levy (1995) as implemented by Wang et al. (1998); this amounts globally to $6.6 \mathrm{Tg} \mathrm{N} \mathrm{a}^{-1}$ including $0.7 \mathrm{Tg} \mathrm{N} \mathrm{a}^{-1}$ from fertilizer application (also held constant over 1950-2050). Biogenic emissions of isoprene and monoterpenes are calculated using the Model of Emissions of Gases and Aerosols from Nature (MEGAN; Guenther et al., 2006), which yields globally $380 \mathrm{Tg} \mathrm{Ca}^{-1}$ isoprene and $98 \mathrm{Tg} \mathrm{Ca}^{-1}$ monoterpenes. We use the climatological biomass burning inventory from Duncan et al. (2003), which yields $1.2 \mathrm{Tg} \mathrm{Sa}^{-1}$ of $\mathrm{SO}_{2}, 6.5 \mathrm{Tg} \mathrm{Na}^{-1}$ of $\mathrm{NO}_{\mathrm{x}}$, 2.9 $\mathrm{Tg} \mathrm{Ca}^{-1}$ of $\mathrm{BC}$, and $23 \mathrm{Tg} \mathrm{Ca}^{-1}$ of POA.

Ammonia emissions are also held constant over the 19502050 period for lack of better information. We use the global inventory of Bouwman et al. (1997) overwritten in Asia by Streets et al. (2003). Seasonal variations of ammonia emissions are described by Park et al. (2004) and are constrained in the US to match wet deposition data (Gilliland et al., 2003). Global emissions total $60 \mathrm{Tg} \mathrm{N} \mathrm{a}^{-1}$ including $40 \mathrm{Tg} \mathrm{N} \mathrm{a}^{-1}$ from anthropogenic sources (mainly agriculture), $14 \mathrm{Tg} \mathrm{N} \mathrm{a}^{-1}$ from natural biogenic activity, and 5.9 $\mathrm{Tg} \mathrm{N} \mathrm{a}^{-1}$ from biomass burning. US emissions total 2.2 $\mathrm{Tg} \mathrm{N} \mathrm{a}^{-1}$ from anthropogenic sources, $0.6 \mathrm{Tg} \mathrm{N} \mathrm{a}^{-1}$ from natural biogenic activity, and $0.04 \mathrm{Tg} \mathrm{N} \mathrm{a}^{-1}$ from biomass burning.

\subsection{Aerosol direct radiative forcing}

We use the GISS GCM 3 (Rind et al., 2007) as modified by Chen et al. (2010b) to calculate all-sky aerosol direct and indirect radiative forcing. The GCM uses monthly mean tropospheric aerosol distributions from GEOS-Chem including sulfate, nitrate, $\mathrm{BC}$, and $\mathrm{OC}(\mathrm{OC} \equiv \mathrm{POA}+\mathrm{SOA})$. $\mathrm{OC}$ is multiplied by 1.4 to convert from the simulated mass of organic carbon to total organic matter (Malm et al., 1994). Aerosol water content is calculated using hygroscopic growth factors from the Global Aerosol Data Set (GADS; Koepke et al., 1997). These aerosol components are incorporated in a climate equilibrium simulation with resolution of $4^{\circ}$ latitude $\times 5^{\circ}$ longitude, 23 vertical levels extending from the surface to $0.002 \mathrm{hPa}$, and fixed present-day sea surface temperatures (SST) and sea ice (Rayner et al., 2003). All-sky aerosol direct radiative forcing is determined within the GCM through parallel radiative calculations including and excluding anthropogenic aerosols. "Anthropogenic" includes contributions from fuel use and industry, but not open biomass burning. Sea salt and soil dust concentrations are from Hansen et al. (2002) and do not influence the direct radiative forcing calculated here.

Radiative forcing calculations are conducted for both external and internal aerosol mixtures. Externally mixed aerosol components are assumed to have a standard gamma size distribution with an area-weighted effective variance of 0.2 and an effective dry radius of $0.3 \mu \mathrm{m}$ for sulfate and ni- trate, $0.5 \mu \mathrm{m}$ for OC, and $0.1 \mu \mathrm{m}$ for BC (Chung and Seinfeld, 2002; Liao et al., 2004). Refractive indices are from Toon et al. (1976) for sulfate and nitrate, and from d'Almeida et al. (1991) for BC and OC. As in Chung and Seinfeld (2002) and Liao et al. (2004), we determine the aerosol extinction efficiency, single scattering albedo, and asymmetry parameter for each aerosol component from a lookup table generated by offline Mie calculations as a function of aerosol size and refractive index. Radiative forcing is calculated by perturbing each aerosol component individually. The total anthropogenic aerosol radiative forcing is calculated by perturbing all aerosol components.

Internally mixed aerosols are composed of sulfate, nitrate, OC, and BC. As in Chung and Seinfeld (2002), we assume that the water uptake of internally mixed particles is equal to the sum of water uptake for externally mixed particles. The internally mixed particles are assumed to have a standard gamma size distribution with surface area-weighted dry radius of $0.3 \mu \mathrm{m}$ and area-weighted variance of 0.2 (Chung and Seinfeld, 2002; Liao et al., 2004; Chen et al., 2007). Optical properties of the internal mixture are calculated using the volume-weighted mean of the refractive indices of the individual components. The radiative forcing of an individual aerosol component is calculated by removing it while holding the remaining components fixed.

\subsection{Aerosol indirect radiative forcing}

Chen et al. (2010b) previously applied the GISS GCM 3 to calculate the aerosol indirect effects initiated by aerosol particles acting as $\mathrm{CCN}$ and thus altering the number concentration $N_{\mathrm{c}}$ of cloud droplets. We follow their approach here using the gridded monthly aerosol concentration fields of SNA and carbonaceous aerosols from GEOS-Chem, together with their sea salt aerosol concentrations. $N_{\mathrm{c}}$ is related to the concentration of water soluble aerosol ions, $m_{\mathrm{i}}$, by a standard power law dependence (Boucher and Lohmann, 1995; Penner et al., 2006):

$\log N_{\mathrm{c}}=A+B \log m_{\mathrm{i}}$

We calculate $N_{\mathrm{c}}$ from the archived GEOS-Chem aerosol distributions. Gridded 3-D monthly mean fields of $A$ and $B$ were obtained by Chen et al. (2010b) from detailed simulations of sulfate and sea salt aerosol microphysics and activation within the GCM (Adams and Seinfeld, 2002; Nenes and Seinfeld, 2003; Fountoukis and Nenes, 2005; Pierce and Adams, 2006). While the microphysical simulations focused on sulfate and sea salt aerosols, the relationship between the coefficients ( $A$ and $B$ ) and $N_{\mathrm{c}}$ is general and additionally applicable to nitrate and hydrophilic carbonaceous aerosols. Chen et al. (2010b) applied these coefficients to global aerosol fields and we use the same $A$ and $B$ fields here for each simulation. Small changes to $A$ and $B$ may be expected as aerosol composition evolves, but we do not 
address this issue here. As in Chen et al. (2010b), $N_{\mathrm{c}}$ is restricted to be $20 \mathrm{~cm}^{-3}$ or greater. This restriction reduces radiative forcing estimates in pristine environments (Chen et al., 2010b) but has little effect in the US, our area of interest.

Following Chen et al. (2010b), we consider the cloud albedo and lifetime effects applied to liquid stratiform clouds only. The cloud albedo effect arises from the enhancement of cloud optical depth from the presence of smaller cloud droplets. The cloud optical depth scales as the inverse of the area-weighted mean effective radius $r_{\mathrm{e}}$ of the cloud droplet size distribution (Del Genio et al., 1996). $r_{\mathrm{e}}$ is related to $N_{\mathrm{c}}$ by

$r_{\mathrm{e}}=\kappa^{\frac{1}{3}}\left[\frac{3 L}{4 \pi N_{\mathrm{c}}}\right]^{\frac{1}{3}}$

where $L$ is the liquid water content of the cloud $\left(\mathrm{cm}^{3}\right.$ water per $\mathrm{cm}^{3}$ air), and $\kappa$ is a constant $(0.67$ over land, 0.80 over ocean, Martin et al., 1994) that relates the volume mean droplet radius and $r_{\mathrm{e}}$. We restrict $r_{\mathrm{e}}$ to be greater than $2 \mu \mathrm{m}$ and less than $20 \mu \mathrm{m}$.

The cloud lifetime effect involves the effect of $N_{\mathrm{c}}$ on the rate of autoconversion of cloud droplets to precipitation. Chen et al. (2010b) introduced a dependence of the autoconversion rate on $N_{\mathrm{c}}$ based on the work of Khairoutdinov and Kogan (2000), which fitted results from large eddy simulations of drizzling stratocumulus:

$$
\frac{\mathrm{d} q_{1}}{\mathrm{~d} t}=-1350 \gamma q_{1}^{2.47} N_{\mathrm{c}}^{-1.79}
$$

where $q_{1}$ is the cloudwater mass content ( $\mathrm{kg}$ water per $\mathrm{kg}$ of air) and $\gamma$ is a tuning parameter added by Hoose et al. (2008) and Chen et al. (2010b) to the original Khairoutdinov and Kogan (2000) equation $(\gamma=1)$ in order to retain GCM climate equilibrium. We find climate equilibrium is retained for $\gamma=12$. This value is consistent with the factor of 2 to 10 underestimate of autoconversion rates found to occur when using gridbox-scale values of $N_{\mathrm{c}}$ (Morales and Nenes, 2010).

The radiative forcing from the cloud albedo effect is calculated for each decade between 1950 and 2050 using parallel radiative calculations, similar to the calculation of the aerosol direct radiative forcing. The parallel radiative calculations are conducted using cloud optical properties determined from $N_{\mathrm{c}}$ distributions with and without US anthropogenic aerosols. In this method, the cloud albedo effect is calculated without the complications of climate feedbacks and can be treated as a traditional radiative forcing. The cloud lifetime effect cannot be calculated in this manner due to coupling with the hydrological cycle. Instead, multi-year climate equilibrium simulations are required to account for the effects of feedback processes on cloud distributions (Denman et al., 2007; Forster et al., 2007). We thus calculate the total aerosol indirect radiative forcing (cloud albedo and lifetime effects) for each decade between 1950 and 2050 by conducting two 60 -yr climate equilibrium simulations, one with and one without US anthropogenic aerosol sources. Both simulations use fixed greenhouse gases, SST, and sea ice for year 2000. The first $10 \mathrm{yr}$ are used for initialization and the following $50 \mathrm{yr}$ (representing climate equilibrium conditions) are used for analysis. Comparison to the radiative forcing of the cloud albedo effect, which is calculated independently as described above, allows separate assessment of the first and second aerosol indirect effects. In order to test the significance of our results, we perform a Student's t-test accounting for autocorrelation as described by Zwiers and von Storch (1995).

Our use of monthly mean aerosol distributions archived from GEOS-Chem does not allow for feedbacks between aerosols and cloud properties (Chapman et al., 2009). These feedbacks are likely very small relative to the changes of aerosol sources studied here. Using monthly mean aerosol distributions does not significantly bias our estimates of the direct radiative effect (Koch et al., 1999), but likely influences our calculation of the aerosol indirect effects due to the nonlinear relationship between aerosol amount and cloud droplet number (Jones et al., 2001).

\section{Evaluation of 1980-2010 US aerosol trends}

We evaluate our simulation of aerosol sources, concentrations, and related long-term trends over the US with 19802009 wet deposition flux data available from the National Atmospheric Deposition Program/National Trend Network (NADP/NTN; http://nadp.sws.uiuc.edu/NTN), and 19902009 surface air concentrations available from the US Interagency Monitoring of Protected Visual Environments (IMPROVE; http://vista.cira.colostate.edu/IMPROVE) and the Clean Air Status and Trends Network (CASTNET; http: //java.epa.gov/castnet). The wet deposition flux data provide constraints on aerosol sources considering that most of $\mathrm{SO}_{2}$, $\mathrm{NO}_{\mathrm{x}}$, and ammonia emitted in the US is deposited within the country by wet and dry processes (Chin and Jacob, 1996; Li et al., 2004; Zhang et al., 2012).

Figure 2 compares the simulated and observed annual wet deposition fluxes and surface concentrations of sulfate, nitrate, and ammonium across the US for the years 1980, 1990, 2000 , and 2010. Observations are three-year average values centered on the decadal year except 2010, which is a twoyear average for 2008-2009. All observation sites meeting the NADP/NTN data completion criterion for at least two of the three years are included. Observations of surface air concentrations are not continuous and some records have substantial gaps. To address this, we first aggregate the observations as seasonal means (DJF, MAM, JJA, SON) for each year, requiring for each season a minimum of 10 data points for IMPROVE (3-day averages) and 5 data points for CASTNET (weekly averages). The seasonal means for the three 


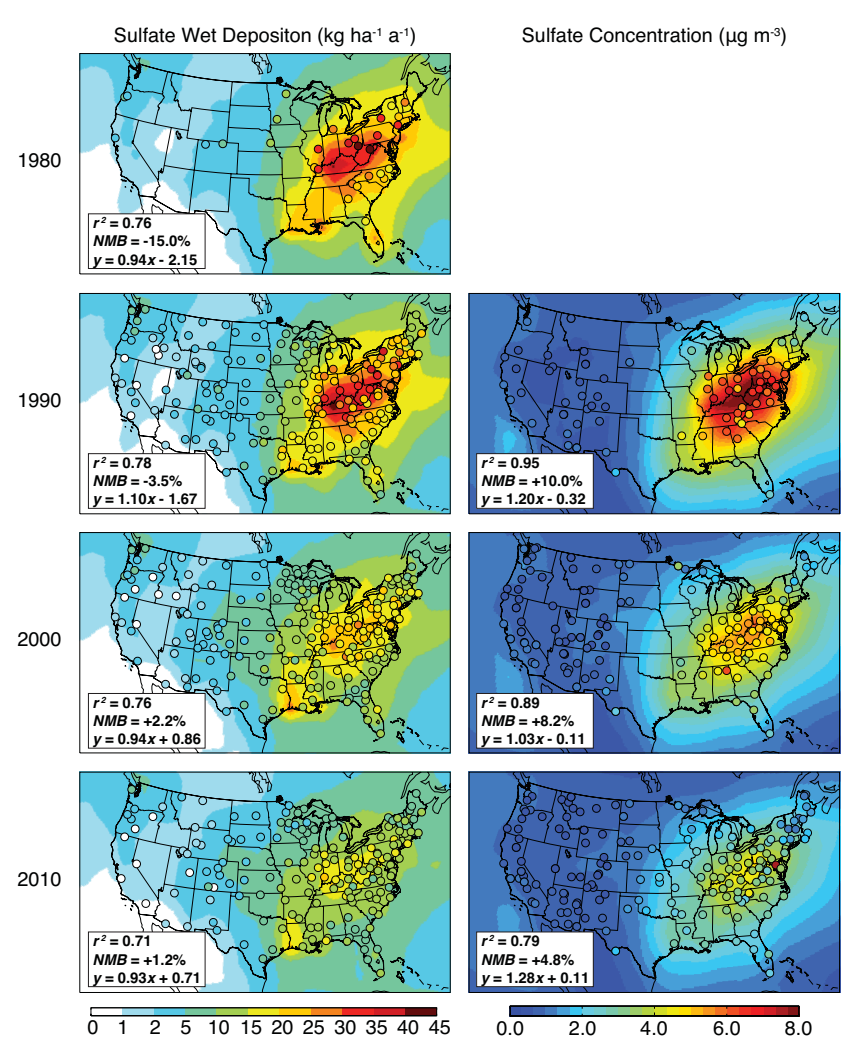

Fig. 2. Sulfate wet deposition fluxes $\left(\mathrm{kg} \mathrm{ha}^{-1} \mathrm{a}^{-1}\right.$, left) and sulfate concentrations in surface air $\left(\mu \mathrm{g} \mathrm{m}^{-3}\right.$, right). Observations (circles) are 3-year averages for 1979-1981 (wet deposition only), 1989-1991, 1999-2001, and 2008-2009. GEOS-Chem model values (background contours) are from decadal time slice simulations with 1980, 1990, 2000, and 2010 emissions. Reduced major axis linear regressions between model and observations are shown inset for each map along with the coefficient of determination $\left(r^{2}\right)$ and normalized mean bias (NMB).

years are then averaged, with the additional requirement that data be available for at least two of the years.

We assemble comparison statistics between the model $(M)$ and observations $(O)$ using the coefficient of determination $\left(r^{2}\right)$, the corresponding reduced-major-axis linear regression, and the normalized mean bias (NMB) calculated for all $N$ sites containing valid data:

$\mathrm{NMB}=\frac{\sum_{i=1}^{N}\left(M_{i}-O_{i}\right)}{\sum_{i=1}^{N} O_{i}}$

We additionally calculate the mean normalized bias MNB $=$ $\frac{1}{N} \sum_{i=1}^{N}\left[\left(M_{i}-O_{i}\right) / O_{i}\right]$. The MNB is generally within $5 \%$ of the NMB and smaller than the NMB.

Figure 2 shows that the model has excellent agreement with observed sulfate wet deposition across the US, capturing the spatial variability $\left(r^{2}=0.71-0.78\right)$ and magnitude. The NMB is less than $4 \%$ for all available decades except $1980(-15 \%)$. Simulated surface concentrations of sul- fate have similar success, capturing spatial variability $\left(r^{2}=\right.$ $0.79-0.95)$ with low bias (10\% or less).

Figure 3 shows the simulated and observed trends in sulfate wet deposition and air concentrations over the 1980 2010 period for the eastern US (east of $100^{\circ} \mathrm{W}$ ). Values are averaged over all sites ( $n$, shown inset) with observations available for more than $25 \mathrm{yr}$ (deposition) and more than $17 \mathrm{yr}$ (concentrations). Observed wet deposition of sulfate decreased by $58 \%$ between 1980 and 2010, consistent with the $56 \%$ reduction in $\mathrm{SO}_{2}$ emissions reported by US EPA (2010). Sulfate aerosol concentrations show a parallel decreasing trend for 1990-2010. Modeled deposition and surface concentrations both decrease by $40 \%$ over 1980 2010, less than observed because of an apparent underestimate of 1980 emissions. The simulated decreases of sulfate deposition and surface concentrations are in better agreement with observations after 1990 .

Figure 4 compares model and observations for ammonium wet deposition fluxes and aerosol concentrations. The model successfully captures the distribution $\left(r^{2}=0.63-0.75\right)$ and magnitude (NMB $<7 \%$ ) of ammonium deposition between 1980 and 2010. The largest deposition is in the agricultural Midwest where emissions are highest. In that region the model is lower than observed. Aerosol ammonium concentrations peak in the industrial Midwest, reflecting the combination of high ammonia emissions and high concentrations of sulfate and nitrate that promote the fractionation of ammonia into the aerosol as ammonium. The model captures this spatial distribution $\left(r^{2}=0.72-0.84\right)$, but is biased high, particularly in $2010(+42 \%)$.

Figure 3 shows observed and simulated 1980-2010 trends in ammonium wet deposition and surface concentrations in the eastern US. The wet deposition data show no significant trend, consistent with the model (which assumes constant ammonia emissions). However, the observed surface concentrations show a large decreasing trend that is only weakly reproduced in the model. This decrease can be explained by decreases in sulfate and nitrate under conditions when the aerosol is neutralized. The inability of the model to capture the decrease in ammonium concentrations reflects a problem with the nitrate trend, as discussed below.

Figure 5 shows the wet deposition and surface air concentrations of nitrate. The model captures the spatial distribution of nitrate deposition $\left(r^{2}=0.71-0.81\right)$, but underpredicts total nitrate wet deposition by $20-33 \%$ in $1980-2000$. The low bias vanishes in 2010, following a decade of large reductions of $\mathrm{NO}_{\mathrm{x}}$ from the energy generation sector (US EPA, 2010). Aerosol nitrate in the model is exclusively ammonium nitrate, and its formation is contingent on ammonia availability (since formation of ammonium sulfate is favored thermodynamically over ammonium nitrate). As such, its simulation tends to compound errors in sulfate and ammonium (Park et al., 2006). Nevertheless, our simulation shows relatively little bias and is improved compared to previous versions of GEOS-Chem (Park et al., 2004, 2006). The observed 

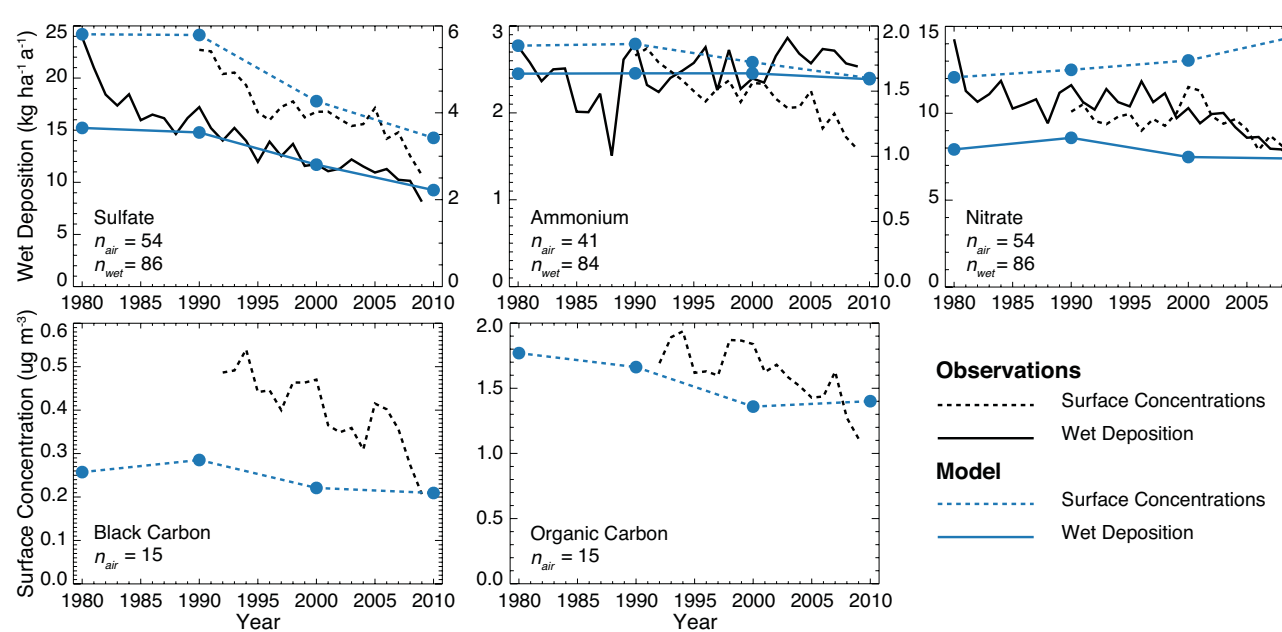

Fig. 3. 1980-2010 trends in wet deposition fluxes (solid) and surface aerosol concentrations (dashed) in the eastern US (east of $100^{\circ}$ W). Values are annual means. Model trends (blue) are compared to observations (black). The number of sites averaged in each calculated trend is given inset. Model values are sampled at the site locations and then averaged.
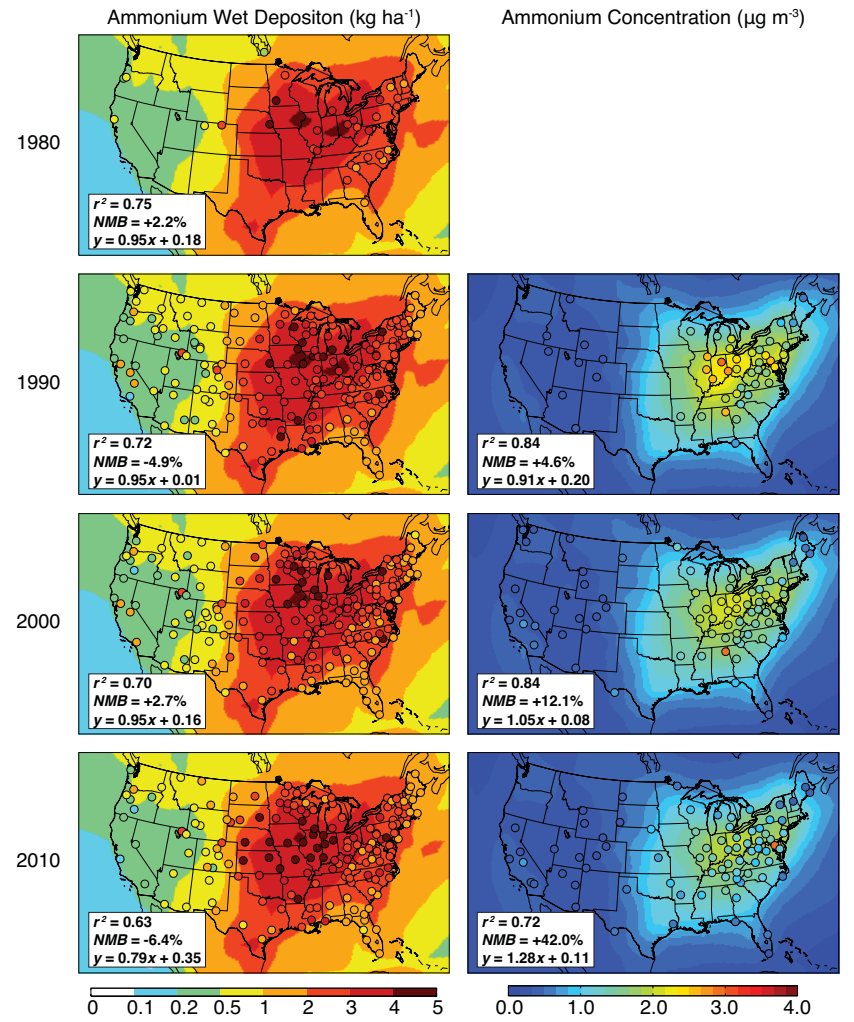

Fig. 4. Same as Fig. 2 but for ammonium.

maximum over the Midwest is well captured by the model where it reflects a balance between ammonia, $\mathrm{NO}_{\mathrm{x}}$, and $\mathrm{SO}_{2}$ source influences.

Observations of nitrate wet deposition show a $33 \%$ decrease from 1980 to 2009, consistent with the reported $36 \%$

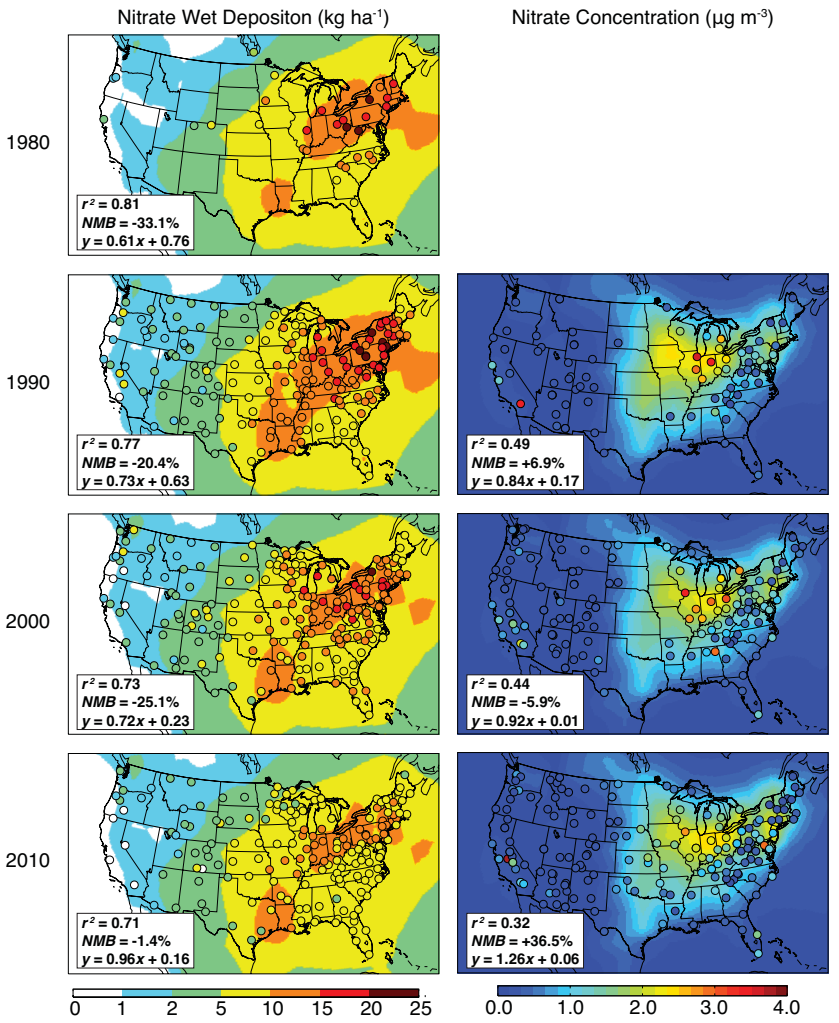

Fig. 5. Same as Fig. 2 but for nitrate.

reduction of $\mathrm{NO}_{\mathrm{x}}$ emissions (US EPA, 2010). Most of this reduction was realized between 2000 and 2009 through the $\mathrm{NO}_{\mathrm{x}}$ State Implementation Plan (SIP) Call. However, the model is largely flat over 1980-2010. The EDGAR emissions used for 1980-2000 are apparently too low. The 
IMAGE A1B projection used for 2000-2010 does not account for the $\mathrm{NO}_{\mathrm{x}}$ SIP Call, and this fortuitously produces a good match to the 2008-2009 observations of nitrate wet deposition (Fig. 5).

Observed aerosol nitrate concentrations were flat from 1990 to 2000 but then decreased by $23 \%$ between 2000 and 2009. In contrast, model concentrations increased weakly during this period because of the decrease in sulfate, resulting in more ammonium being available for ammonium nitrate formation (West et al., 1999). The observed 2000-2009 decrease in nitrate, rapid decrease in sulfate, and near constant supply of ammonia seems at odds with current understanding of SNA thermodynamics. We did not explore this issue further, but it warrants future study.

Figure 6 compares simulated and observed surface concentrations of BC and OC for 1990-2010. Biogenic VOCs are a major source of $\mathrm{OC}$ in the Southeast. Open fires are an important component of observed variability for $\mathrm{BC}$ and $\mathrm{OC}$ in the West and in the Southeast (Park et al., 2007). These fires are not well reproduced by the model on an event basis, explaining in part the relatively low correlations between model and observed concentrations. The model is also biased low by $15-40 \%$ on average. Previous GEOS-Chem studies did not show as severe a bias because the $\mathrm{BC}$ and $\mathrm{OC}$ sources were fitted to reproduce the observations (Park et al., 2003) and included significantly higher biomass burning emissions (Park et al., 2003, 2006). Previous models using the Bond et al. (2004) inventory (similar to Bond et al. (2007) used here) also underestimate BC in North America (Koch et al., 2007, 2009).

Figure 3 shows that observed $\mathrm{BC}$ and $\mathrm{OC}$ concentrations over the US decreased by $50 \%$ and $34 \%$ respectively between 1990 and 2009. The model trends are much weaker, with $\mathrm{BC}$ and $\mathrm{OC}$ concentrations decreasing by $27 \%$ and $16 \%$ respectively, as driven by the trends in the Bond et al. (2007) emission inventory and the IMAGE A1B projection. The mismatch between simulated and observed trends reduces the model low bias in 2010 to $20 \%$ for BC and $15 \%$ for OC.

Overall, the model shows mixed success in the simulation of 1990-2010 aerosol trends. We have an excellent simulation for sulfate, which accounts for $65 \%$ of anthropogenic aerosol mass and $78 \%$ of associated aerosol optical depth over the eastern US (Table 1). This gives us some confidence in the model representation of overall trends in aerosol radiative forcing, and we will quantify below the related error using the trend information in Fig. 3. In view of our underestimate of BC for the 1990-2000 period, we will focus our discussion of BC radiative forcing on present-day (2010) when the simulation shows no significant bias.

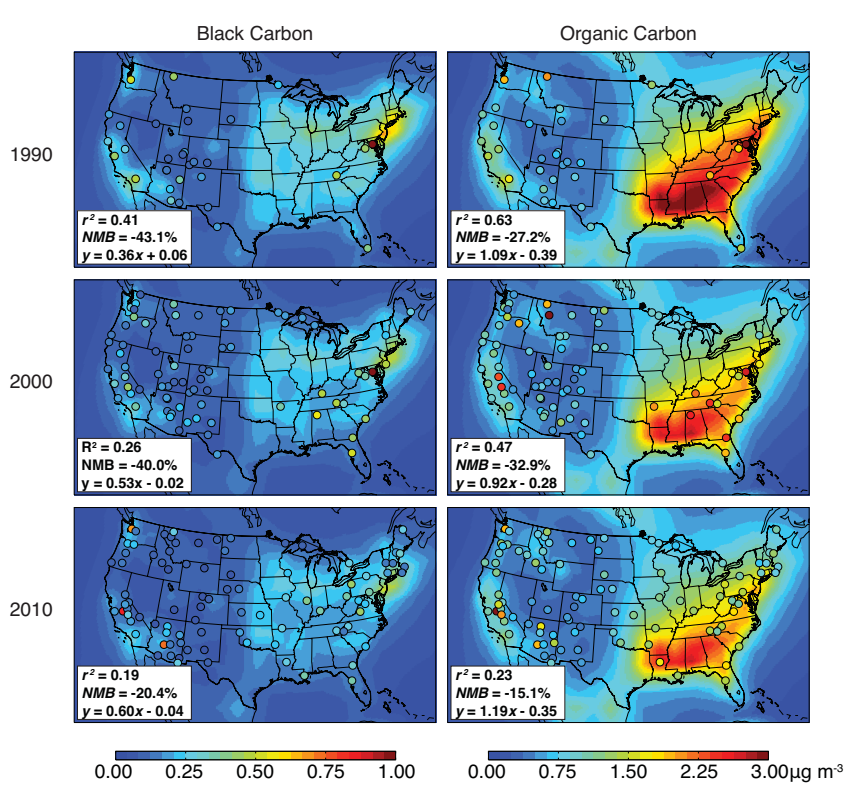

Fig. 6. Black carbon (left) and organic carbon (right) concentration in surface air $\left(\mu \mathrm{g} \mathrm{m}^{-3}\right)$. Observations (circles) are 3-yr averages for 1989-1991, 1999-2001, and 2008-2009. GEOS-Chem model values (background contours) are from the decadal time slice simulations with 1990, 2000, and 2010 emissions. Reduced major axis linear regressions between model and observations are shown inset for each map along with the coefficient of determination $\left(r^{2}\right)$ and normalized mean bias (NMB).

\section{Aerosol direct radiative forcing from US anthropogenic sources}

Figure 7 (top) shows the calculated annual mean aerosol direct radiative forcing for the peak in US anthropogenic aerosols in year 1980. The values in Fig. 7 assume an internal aerosol mixture, the forcing increases by $10 \%$ for an external mixture due to the lesser effect of BC absorption (Chylek et al., 1995; Jacobson, 2000). The forcing is strongly localized over the eastern US, where it reaches $-4.9 \mathrm{~W} \mathrm{~m}^{-2}$. This more than offsets for that region the 1980 radiative forcing from the long-lived greenhouse gases $\left(+1.8 \mathrm{~W} \mathrm{~m}^{-2}\right)$. On a global scale the aerosol direct radiative forcing from US anthropogenic aerosol sources in 1980 is $-0.10 \mathrm{~W} \mathrm{~m}^{-2}$, $25 \%$ of our computed global aerosol direct radiative forcing of $-0.41 \mathrm{~W} \mathrm{~m}^{-2}$ from anthropogenic sources worldwide in 1980. By 2010 we find that the radiative forcing from anthropogenic US aerosol sources has decreased to $-0.03 \mathrm{~W} \mathrm{~m}^{-2}$ globally, amounting to just $6 \%$ of the total from worldwide anthropogenic sources $\left(-0.54 \mathrm{~W} \mathrm{~m}^{-2}\right)$, reflecting the rapid decline of emissions in the US and growth in Asia (Fig. 1). The decline of the US contribution to the global mean aerosol radiative forcing results largely from decreasing sulfate aerosol $\left(+0.07 \mathrm{~W} \mathrm{~m}^{-2}\right)$ with a smaller opposing role from decreasing black carbon $\left(-0.01 \mathrm{~W} \mathrm{~m}^{-2}\right)$. 
Table 1. Aerosol direct radiative forcing from global and US anthropogenic sources $(2010)^{\mathrm{a}}$.

\begin{tabular}{|c|c|c|c|c|c|c|c|c|c|}
\hline & \multirow{2}{*}{$\frac{\text { Emissions }\left(\mathrm{Tg} \mathrm{a}^{-1}\right)^{\mathrm{b}}}{\text { Global }}$} & \multicolumn{2}{|c|}{ Burden $(\mathrm{Gg})^{\mathrm{c}}$} & \multicolumn{2}{|c|}{$\mathrm{AOD} \times 1000^{\mathrm{d}}$} & \multicolumn{2}{|c|}{$\begin{array}{c}\text { Direct Radiative Forcing } \\
\text { External Mixture }\left(\mathrm{W} \mathrm{m}^{-2}\right)\end{array}$} & \multicolumn{2}{|c|}{$\begin{array}{c}\text { Direct Radiative Forcing } \\
\text { Internal Mixture }\left(\mathrm{W} \mathrm{m}^{-2}\right)\end{array}$} \\
\hline & & Global & Eastern US & Global & Eastern US & Global & Eastern US | & Global & Eastern US \\
\hline Sulfate & $80.3(8 \%)$ & $390(6.5 \%)$ & $8.9(65 \%)$ & $34.2(6.6 \%)$ & $83.2(67 \%)$ & $-0.65(6.9 \%)$ & $-1.85(66 \%)$ & $-0.62(7.0 \%)$ & $-1.82(64 \%)$ \\
\hline Black Carbon & $4.3(7.1 \%)$ & $69.1(6.3 \%)$ & $1.5(66 \%)$ & $0.9(6.6 \%)$ & $1.9(64 \%)$ & $+0.19(5.5 \%)$ & $+0.32(65 \%)$ & $+0.30(5.0 \%)$ & $+0.49(67 \%)$ \\
\hline Primary Organic Aerosol & $8.1(5.5 \%)$ & $110(6.1 \%)$ & $2.3(69 \%)$ & $1.4(6.7 \%)$ & $3.2(69 \%)$ & $-0.14(6.1 \%)$ & $-0.25(67 \%)$ & $-0.11(5.5 \%)$ & $-0.20(68 \%)$ \\
\hline Total & - & - & - & $42.6(6.1 \%)$ & $106(66 \%)$ & $-0.67(6.5 \%)$ & $-2.13(65 \%)$ & $-0.54(6.1 \%)$ & $-1.88(64 \%)$ \\
\hline
\end{tabular}

${ }^{\text {a }}$ Model values for anthropogenic perturbations (excluding biomass burning) averaged globally and over the eastern US (east of $100^{\circ} \mathrm{W}$ ). The contribution from US anthropogenic sources is shown in parentheses.

b Sulfate emissions as precursor $\mathrm{SO}_{2}\left(\mathrm{Tg} \mathrm{S} \mathrm{a}^{-1}\right)$; nitrate emissions as precursor $\mathrm{NO}_{x}\left(\mathrm{Tg} \mathrm{N} \mathrm{a}^{-1}\right)$; black carbon $\left(\mathrm{Tg} \mathrm{C} \mathrm{a}^{-1}\right)$; primary organic aerosol $\left(\mathrm{Tg} \mathrm{C}^{-1}\right)$.

c Sulfate burden as Gg S; nitrate burden as Gg N; black carbon burden as Gg C; organic carbon burden as Gg C.

d Aerosol optical depth (AOD) computed for an external mixture.

Table 1 presents the 2010 anthropogenic perturbations to aerosol abundances and optical properties averaged over the globe and over the eastern US (east of $100^{\circ} \mathrm{W}$ ). We see that the US contributes only $5 \%$ of the global mean anthropogenic radiative forcing from absorbing aerosols (global mean: $+0.30 \mathrm{~W} \mathrm{~m}^{-2}$ ) while providing $6.3 \%$ of the forcing from scattering aerosols (global mean: $-0.83 \mathrm{~W} \mathrm{~m}^{-2}$ ). We show in Leibensperger et al. (2012) that even though the aerosol radiative forcing from US anthropogenic sources is very small on a global scale, the large regional forcing elicits a strong regional climate response over the eastern US.

Figure 8 (top) shows the 1950-2050 evolution of the annual mean aerosol direct radiative forcing from US anthropogenic sources averaged over the eastern US (east of $100^{\circ} \mathrm{W}$ ). It peaks in $1970-1990$ at $-2.0 \mathrm{~W} \mathrm{~m}^{-2}$ (internal mixture). When externally mixed, the radiative forcing is stronger, $-2.2 \mathrm{~W} \mathrm{~m}^{-2}$. The external mixture has $5 \%$ lower column integrated aerosol optical depth, $2 \%$ higher single scattering albedo, and $1 \%$ higher asymmetry parameter (forward scattering is increased) over the eastern US. In the external mixture the radiative forcing of $\mathrm{BC}$ is $40 \%$ lower and that of sulfate and nitrate is 5-7\% higher. OC shares common sources with $\mathrm{BC}$, which makes its contribution to radiative forcing more sensitive to mixing state; it has $30 \%$ higher radiative forcing in an external mixture than an internal mixture.

The anthropogenic radiative forcing trends in Fig. 8 mirror the model US emission trends in Fig. 1. We previously evaluated the model trends for 1980-2010 using observed records of wet deposition and aerosol concentrations (Fig. 3). For sulfate, which is the dominant anthropogenic radiative forcing agent, the model closely reproduces the observed trends for $1990-2010$, but is $15 \%$ too low in 1980, suggesting a corresponding error in the aerosol radiative forcing estimate for 1980 . For BC, the model is $40 \%$ too low in 1990 and 2000 but the bias decreases to $20 \%$ in 2010 , reflecting a steep decline in the observed concentrations. Radiative forcing from $\mathrm{OC}$ is relatively small due to its lower extinction efficiency and modest anthropogenic component. The anthropogenic component of OC simulated here consists mainly of
Radiative Forcing from US Anthropogenic Aerosols in $1980\left(\mathrm{~W} \mathrm{~m}^{-2}\right)$
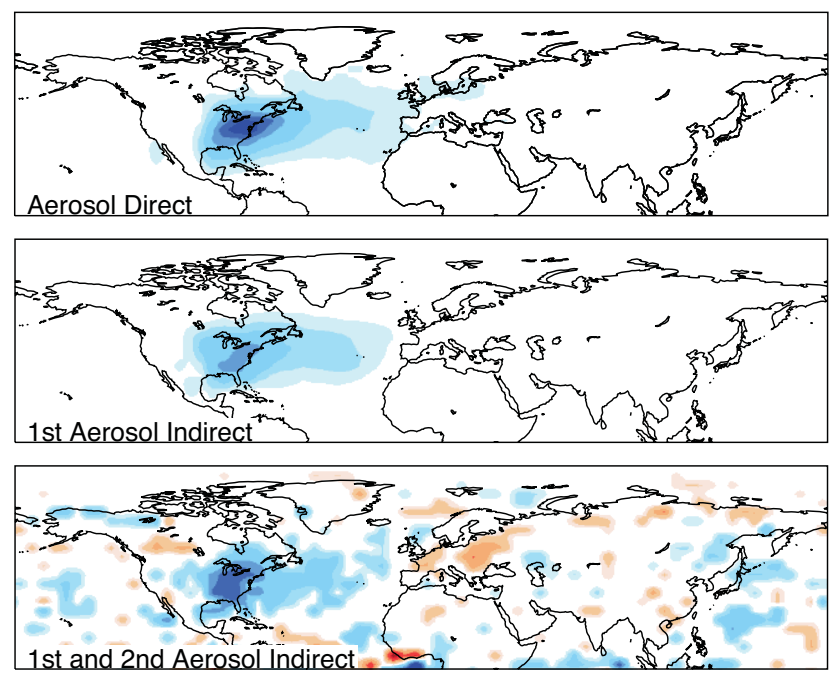

$\begin{array}{lllllllllllllll} & -5 . & -4 . & -3 . & -2 . & -1 . & -0.5 . & -0.2 & 0.2 & 0.5 & 1 . & 2 . & 3 . & 4 . & 5 .\end{array}$

Fig. 7. Annual mean aerosol direct (top), first indirect (middle), and total indirect (bottom) radiative forcing from US anthropogenic sources for year 1980. The aerosol direct effect is calculated assuming an internal mixture. Assuming an external mixture would increase the radiative forcing over the US by $10 \%$. The direct and first indirect effects are calculated with parallel radiative calculations using perturbed aerosol abundances (direct) and cloud optical properties (first indirect). The total aerosol indirect effect is calculated by difference between 50-year climate equilibrium simulations with and without US anthropogenic aerosols. White areas show no significant change at the 95 th percentile of confidence. The global mean values are $-0.07 \mathrm{~W} \mathrm{~m}^{-2}$ for the direct effect, $-0.05 \mathrm{~W} \mathrm{~m}^{-2}$ for the first indirect effect, and $-0.08 \mathrm{~W} \mathrm{~m}^{-2}$ for the total indirect effect.

POA with limited changes in SOA. Radiative forcing from nitrate is weaker than its annual mean concentration would imply because it is most abundant in winter when insolation is weak. 

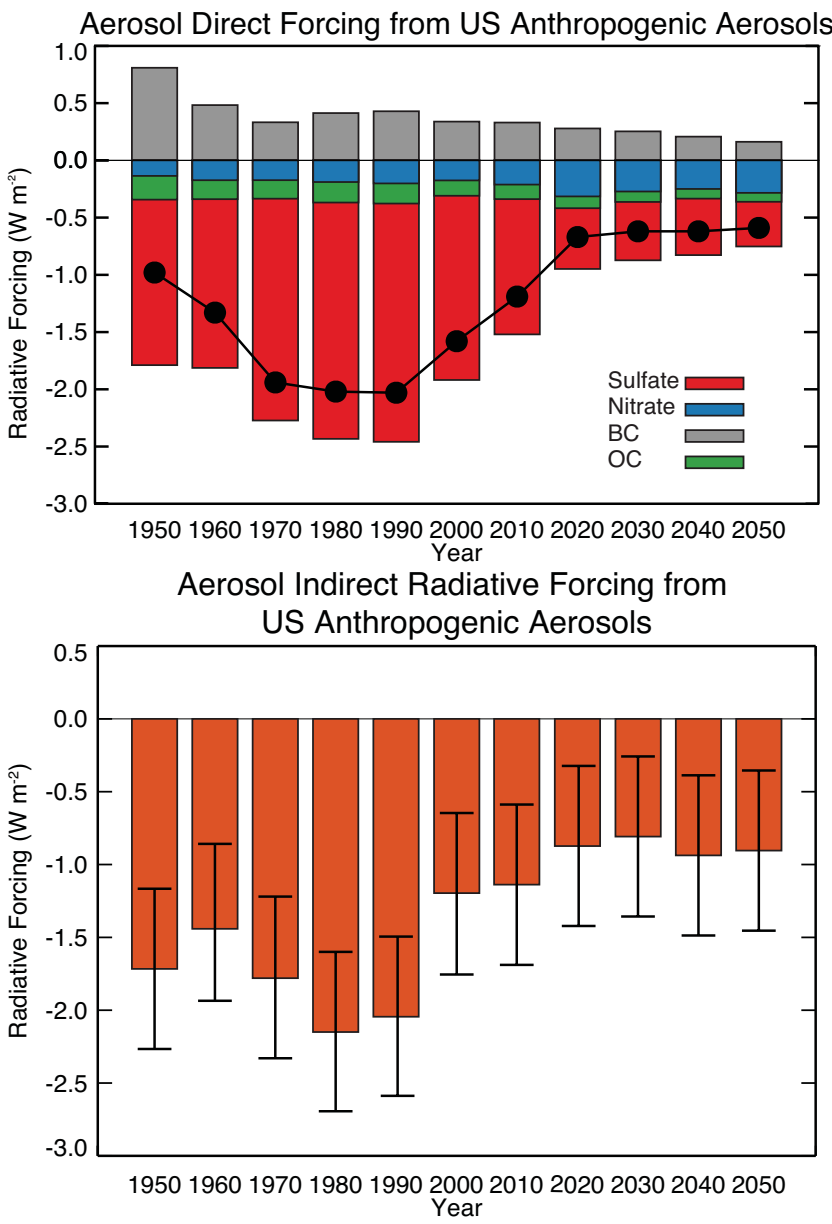

Fig. 8. 1950-2050 evolution of aerosol direct (top) and total (first + second) indirect radiative forcing (bottom) from US anthropogenic sources over the eastern US (east of $100^{\circ} \mathrm{W}$ ). Circles represent the net direct radiative forcing and the bars give the contributions from the different components. The direct radiative forcing calculations are for an internal aerosol mixture. Aerosol indirect radiative forcing is calculated as the difference between two 50-yr equilibrium climate simulations with vs. without US anthropogenic aerosols. The error bars represent the $95 \%$ confidence interval of the forcing based on model interannual variability.

We can use the data in Fig. 3 to estimate the model error in computing the change in anthropogenic aerosol direct radiative forcing from 1980 to 2010 . Our best model estimate for this change (adding the contribution from the different aerosol components, black line in Fig. 8 ) is $+0.78 \mathrm{~W} \mathrm{~m}^{-2}$. Applying scaling factors for errors in the individual components based on Fig. 3, and assuming that the model bias for BC in 1990 applies also to 1980, we obtain a change in anthropogenic radiative forcing constrained by observations of $+0.87 \mathrm{~W} \mathrm{~m}^{-2}$, about $10 \%$ larger. In addition to model biases in aerosol loading, uncertainties surround the aerosol radiative properties required to connect aerosol concentrations to radiative forcing. Schulz et al. (2006) compared the radiative forcing estimates of nine models using identical emission datasets. The relative error in radiative forcing attributable to aerosol optical properties varied slightly between aerosol components but was about $50 \%$. We adopt this value as the uncertainty of our radiative forcing calculations.

Future projection of US emissions from the IMAGE model applied to the IPCC A1B scenario (Fig. 1) indicates a continued decrease in aerosol direct radiative forcing (Fig. 8), but with little change past 2020. Aerosol radiative forcing will have decreased by almost a factor of 4 from its peak strength in 1970-1990.

Two policy-relevant implications can be drawn from the trends in US aerosol direct radiative forcing in Fig. 8. First, future decrease in aerosol radiative forcing due to reductions in anthropogenic emissions will likely be smaller than the decrease that has already been realized over 1980-2010. Thus most of the climate response from controlling US anthropogenic aerosol sources has already been realized, and almost all will have been realized by 2020 . Second, the present-day (2010) radiative forcing from US anthropogenic $\mathrm{BC}$ is small (and even less if external forcing is assumed), so that emission controls targeting BC provide only limited climate benefit. These emission controls would benefit public health but are not an effective "win-win" scenario for both US public health and climate. The climate benefit of reducing US BC emissions is further complicated when considering the effects of co-emitted aerosol species and cloud interactions (Bauer et al., 2010; Chen et al., 2010a; Koch and Del Genio, 2010; Unger et al., 2010). We elaborate further on the implications of US anthropogenic BC in Leibensperger et al. (2012).

\section{Aerosol indirect radiative forcing from US anthropogenic sources}

Estimating the aerosol indirect radiative forcing from cloud albedo and lifetime effects is far more uncertain than the direct radiative forcing. Uncertainties relate to the conversion from aerosol mass concentration to cloud droplet number concentration $\left(N_{\mathrm{c}}\right)$ and from there to cloud optical properties, including the effective cloud droplet radius $\left(r_{\mathrm{e}}\right)$ and the spatial distribution of liquid water path (vertical column of liquid water amount, $\mathrm{g} \mathrm{m}^{-2}$ ). Particularly uncertain is the subgrid variability of these parameters. Table 2 compares the global mean cloud properties computed from our model to Chen et al. (2010b) (same GCM and cloud droplet parameterization, but different aerosol concentrations) and to other values in the literature. Our values are consistent with the published ranges. Chen et al. (2010b) report higher global mean $N_{\mathrm{c}}$ but similar cloud forcing, which may reflect differences in the geographical and vertical distributions of $N_{\mathrm{c}}$.

Figure 9 shows the change in liquid stratiform cloud properties due to US anthropogenic aerosols in 1980 including column $N_{\mathrm{c}}$, effective cloud droplet radius, and cloud optical 
Table 2. Global mean cloud properties ${ }^{\mathrm{a}}$.

\begin{tabular}{lrrr}
\hline & $\begin{array}{r}\text { This } \\
\text { Work }\end{array}$ & $\begin{array}{r}\text { Chen et } \\
\text { al. }(2010 \mathrm{~b})\end{array}$ & $\begin{array}{r}\text { Other } \\
\text { Studies }^{\mathrm{b}}\end{array}$ \\
\hline Total Column $N_{\mathrm{c}}\left(10^{10} \mathrm{~m}^{-2}\right)$ & 3.8 & 6.2 & $2.1-7.6^{\mathrm{c}}$ \\
$N_{\mathrm{c}}$ at $850 \mathrm{hPa}\left(\mathrm{cm}^{-3}\right)$ & 83.0 & 122.2 & $75.0-135.0^{\mathrm{d}}$ \\
$r_{\mathrm{e}}$ at cloud top $(\mu \mathrm{m})^{\mathrm{e}}$ & 12.9 & 12.2 & $6.8-13.3^{\mathrm{f}}$ \\
LWP $\left(\mathrm{g} \mathrm{m}^{-2}\right)$ & 111.3 & 111.5 & $41.5-110.0^{\mathrm{g}}$ \\
TOA SW CF $\left(\mathrm{W} \mathrm{m}^{-2}\right)$ & -55.2 & -53.8 & $-46.0--61.0^{\mathrm{h}}$ \\
\hline
\end{tabular}

a Cloud droplet number concentration $\left(N_{\mathrm{c}}\right)$, effective area-weighted mean cloud droplet radius $\left(r_{\mathrm{e}}\right)$, liquid water path (LWP), top-of-atmosphere shortwave cloud forcing (TOA SW CF).

b Ranges from the literature including models and observation analyses.

c Menon et al. (2002), Gettelman et al. (2008), Hoose et al. (2008), and Salzmann et al. (2010).

d Penner et al. (2006).

e Modeled values of $r_{\mathrm{e}}$ are multiplied by $2^{1 / 3}$ to approximate the cloud top conditions of satellite retrievals (Meskhidze et al., 2007).

f Menon et al. (2002), Kristjánsson et al. (2005), Penner et al. (2006), Storelvmo et al. (2006), Gettelman et al. (2008), and Barahona et al. (2011).

g Kristjánsson et al. (2005), Penner et al. (2006), Storelvmo et al. (2006), Gettelman et al. (2008), Hoose et al. (2008), and Salzmann et al. (2010).

h Menon et al. (2002), Kristjánsson et al. (2005), Penner et al. (2006), Gettelman et al. (2008), and Salzmann et al. (2010)

depth. US anthropogenic aerosols increase column integrated $N_{\mathrm{c}}$ by up to $8 \times 10^{10} \mathrm{~m}^{-2}(40 \%)$ which reduces the effective cloud droplet radius of liquid stratiform clouds by up to $1.2 \mu \mathrm{m}(15 \%)$, and increases the warm cloud optical depth by more than $3(17 \%)$. The resulting radiative forcing from the cloud albedo effect amounts to $67 \%$ of the direct forcing $\left(-1.3 \mathrm{~W} \mathrm{~m}^{-2}\right.$ averaged over the US east of $100^{\circ} \mathrm{W}$ ) on an annual basis (Fig. 7 middle) and reaches up to $-3.0 \mathrm{~W} \mathrm{~m}^{-2}$ in the Southeast. Similar to the aerosol direct effect, radiative forcing from the cloud albedo effect is largely confined to the US and the downwind North Atlantic.

Figure 7 (bottom) shows the total aerosol indirect radiative forcing (cloud albedo and lifetime) from US anthropogenic aerosols in 1980. The indirect forcing is calculated as the mean difference in net top of the atmosphere radiation between 50-yr simulations with and without US anthropogenic aerosol sources, as described in Sect. 2.3. It is noisier than the direct radiative forcing, largely reflecting the cloud lifetime effect, but is similarly concentrated over the eastern US and the North Atlantic downwind. The annual mean total indirect forcing in the eastern US (east of $100^{\circ} \mathrm{W}$ ) is $-2.2 \mathrm{~W} \mathrm{~m}^{-2}$ for $1980,10 \%$ larger than the direct effect and $70 \%$ larger than the cloud albedo effect alone. The total indirect effect of US anthropogenic aerosols is also slightly larger globally $\left(-0.08 \mathrm{~W} \mathrm{~m}^{-2}\right.$ total indirect vs. $-0.07 \mathrm{~W} \mathrm{~m}^{-2} \mathrm{di}^{-}$ rect).

Figure 8 (bottom) shows our computed 1950-2050 trend in aerosol indirect radiative forcing over the eastern US (east of $100^{\circ} \mathrm{W}$ ) from US anthropogenic sources. The error bars indicate the $95 \%$ confidence interval of this difference based on model interannual variability. We estimate this uncertainty to be $\pm 0.5 \mathrm{~W} \mathrm{~m}^{-2}$. The trend in indirect forcing is consistent with the evolution of $\mathrm{SO}_{2}$ emissions (Fig. 1) and aerosol direct forcing (Fig. 8 top). Indirect forcing peaks in

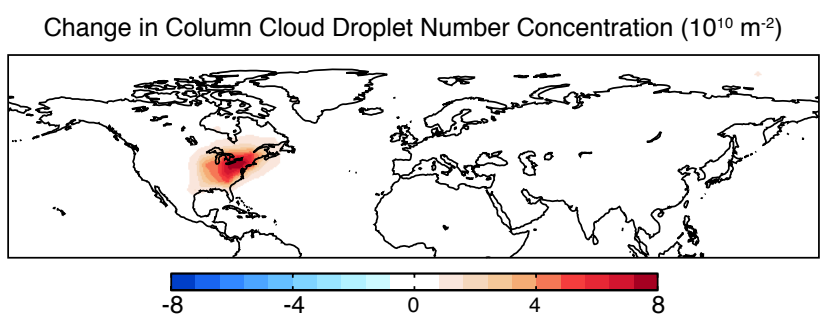

Change in Liquid Stratiform Cloud Optical Depth

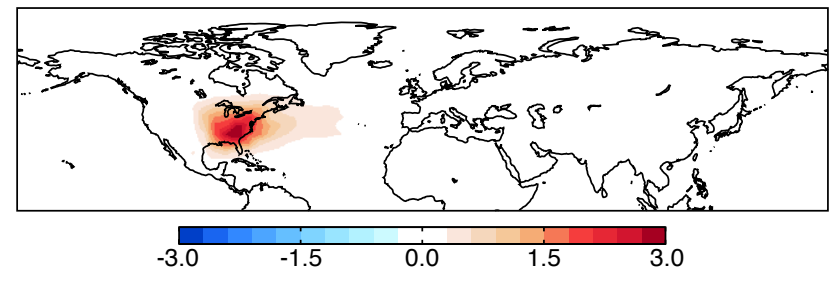

Change in Liquid Stratiform $r_{e}$ at Cloud Top $(\mu \mathrm{m})$

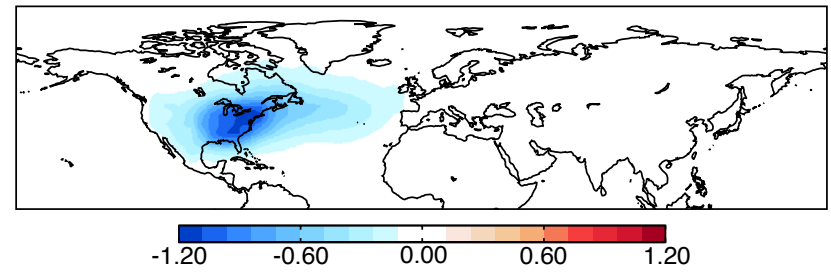

Fig. 9. Effect of US anthropogenic aerosols on column integrated cloud droplet number concentration, liquid stratiform cloud droplet effective radius at cloud top $\left(r_{\mathrm{e}}\right)$, and liquid stratiform cloud optical depth. Values are annual model means for 1980.

1970-1990 at a value of $-2.0 \mathrm{~W} \mathrm{~m}^{-2}$, the same magnitude as the aerosol direct effect. $\mathrm{SO}_{2}$ regulations cause a sharp decrease in forcing with a change of $+1.0 \mathrm{~W} \mathrm{~m}^{-2}$ between 1990 and 2010, and little change afterward.

\section{Conclusions}

Efforts to improve air quality through aerosol source reductions could have significant regional climate implications due to the strong and localized radiative forcing exerted by aerosols. The US is of particular interest for investigating this effect as aerosol concentrations peaked in the 1970-1990 period, have decreased rapidly since then, and are projected to continue decreasing in the future. We used here the GEOSChem CTM applied to historical emission inventories and future projections (IPCC A1B scenario) to simulate global trends in aerosol concentrations over the 1950-2050 period, and we applied those in the GISS GCM to calculate the direct and indirect radiative forcings from US anthropogenic aerosol sources. A companion paper by Leibensperger et al. (2012) examines the resulting climate response over the US and globally.

A prominent feature of the aerosol radiative forcing history from US sources is the rapid 1980-2010 decline driven by air quality regulations. We tested our reconstruction of 
this history with observed spatial distributions and long-term trends in wet deposition (1980-2010) and aerosol concentrations (1990-2010). We reproduce successfully the observed $45 \%$ decline of sulfate wet deposition and concentrations between 1990 and 2010, but underestimate the earlier 1980 to 1990 decline. Ammonium wet deposition fluxes show no long-term trend in the observations or in the model (where ammonia emissions are assumed constant). The combination of decreasing $\mathrm{SO}_{2}$ emissions and constant ammonia emissions leads to a weak increasing trend of nitrate in the model, but observations show a decrease. Observations of BC and OC show stronger 1980-2010 declines than simulated by the model, implying a faster decline of emissions than is represented in current inventories.

We calculated a global direct radiative forcing from US anthropogenic aerosol sources of $-0.10 \mathrm{~W} \mathrm{~m}^{-2}$ in 1980 when the sources were at their peak. This forcing is strongly localized over the eastern US and downwind North Atlantic. It averages $-2.0 \mathrm{~W} \mathrm{~m}^{-2}$ over the eastern US (east of $100^{\circ} \mathrm{W}$ ), including $-2.0 \mathrm{~W} \mathrm{~m}^{-2}$ from sulfate, $+0.4 \mathrm{~W} \mathrm{~m}^{-2}$ from $\mathrm{BC}$, $-0.2 \mathrm{~W} \mathrm{~m}^{-2}$ from nitrate, and $-0.2 \mathrm{~W} \mathrm{~m}^{-2}$ from OC. These values assume an internal aerosol mixture; an external mixture would increase the overall negative radiative forcing by $10 \%$ due to decreased absorption by BC. Based on prior modeling studies, our radiative forcing estimates have an uncertainty of about $50 \%$ due to the uncertainty of aerosol radiative properties.

The direct radiative forcing from US anthropogenic aerosols declined strongly between 1970-1990 and 2010, largely reflecting the decline in $\mathrm{SO}_{2}$ emissions. The global forcing declined to $-0.03 \mathrm{~W} \mathrm{~m}^{-2}$ by 2010 , amounting to only $6 \%$ of the forcing from global anthropogenic aerosol sources (as compared to $25 \%$ in 1980). The forcing over the eastern US declined by $0.78 \mathrm{~W} \mathrm{~m}^{-2}$ in the model between 1990 and 2010. Correction to this model estimate based on the observed trends of wet deposition fluxes and concentrations would imply a decline of $0.87 \mathrm{~W} \mathrm{~m}^{-2}$.

We calculated the aerosol indirect forcing including the first and second indirect effects (cloud albedo and cloud lifetime) applied to warm stratiform clouds. US anthropogenic aerosols potentially alter properties of convective and ice clouds but the scientific understanding of these effects is very low (Denman et al., 2007). We found that the indirect radiative forcing from US anthropogenic aerosol sources is mainly localized over the eastern US and North Atlantic, similarly to the direct forcing, and shows similar temporal trends over the 1950-2050 period. While uncertainties are large, 1980 values over the eastern US average $-2.2 \mathrm{~W} \mathrm{~m}^{-2}$. The indirect forcing is similar in magnitude to the direct radiative forcing. About $60 \%$ of the indirect radiative forcing comes from the cloud albedo effect.

We project that by 2050 the direct and indirect radiative forcings over the eastern US from US anthropogenic sources will have decreased to $-0.6 \mathrm{~W} \mathrm{~m}^{-2}$ and $-0.9 \mathrm{~W} \mathrm{~m}^{-2}$, respectively, $71 \%$ and $55 \%$ weaker than the 1980 peak, and
$46 \%$ and $25 \%$ weaker than present-day (2010). Nitrate is expected to become a major component of the aerosol radiative forcing in 2050 as $\mathrm{NO}_{\mathrm{x}}$ emissions decrease more slowly than $\mathrm{SO}_{2}$ emissions. Essentially all of the 1980-2050 decrease in radiative forcing occurs over the 1990-2020 period. US anthropogenic emissions are sufficiently weak by now that little additional reduction in forcing is expected in the future even with the projected continued decrease in emissions.

The positive radiative forcing from $\mathrm{BC}$ anthropogenic emissions in the US is presently too small to provide significant climate leverage from future emission controls targeted at BC. Our simulations significantly underestimate US $\mathrm{BC}$ concentrations in earlier periods but we have confidence in our estimate of the present-day radiative forcing from US anthropogenic $\mathrm{BC}$ because of the ability of the model to reproduce observed BC concentrations in the US in 2010 (20\% low bias). Although our radiative forcing estimate does not include the semi-direct effects associated with cloud evaporation (Koch and Del Genio, 2010), transient-climate simulations presented in our companion paper (Leibensperger et al., 2012) do include these effects and confirm the climate insensitivity to present-day anthropogenic sources of $\mathrm{BC}$ in the US. This insensitivity merely reflects the relatively small magnitude of $\mathrm{BC}$ emissions from the US and does not challenge the argument that decreasing global BC emissions would have significant benefit for both air quality and climate (Jacobson, 2002; Bond, 2007; Grieshop et al., 2009; Shindell et al., 2012). In particular, an important regional climate benefit could be achieved in Asia, where BC sources are much larger than in the US (Lu et al., 2011).

Acknowledgements. This work was supported by the Electric Power Research Institute (EPRI) and an EPA Science to Achieve Results (STAR) Graduate Research Fellowship to Eric Leibensperger. The EPRI and EPA have not officially endorsed this publication and the views expressed herein may not reflect those of the EPRI and EPA. This work utilized resources and technical support offered by the Harvard University School of Engineering and Applied Science Instructional and Research Computing Services. We would like to thank Jack Yatteau for computational assistance. We thank the editor and two anonymous reviewers whose comments helped improve this work.

Edited by: M. Kanakidou

\section{References}

Adams, P. J. and Seinfeld, J. H.: Predicting global aerosol size distributions in general circulation models, J. Geophys. Res.Atmos., 107, 4370, doi:10.1029/2001JD001010, 2002.

Albrecht, B.: Aerosols, cloud microphysics, and fractional cloudiness, Science, 245, 1227, doi:10.1126/science.245.4923.1227, 1989.

Alexander, B., Park, R. J., Jacob, D. J., Li, Q., Yantosca, R. M., Savarino, J., Lee, C. C. W., and Thiemens, M. H.: Sulfate formation in sea-salt aerosols: Constraints from 
oxygen isotopes, J. Geophys. Res.-Atmos., 110, D10307, doi:10.1029/2004JD005659, 2005.

Andres, R. and Kasgnoc, A.: A time-averaged inventory of subaerial volcanic sulfur emissions, J. Geophys. Res.-Atmos., 103, 25251-25261, 1998.

Barahona, D., Sotiropoulou, R., and Nenes, A.: Global distribution of cloud droplet number concentration, autoconversion rate, and aerosol indirect effect under diabatic droplet activation, J. Geophys. Res., 116, D09203, doi:10.1029/2010JD015274, 2011.

Bauer, S. E., Menon, S., Koch, D., Bond, T. C., and Tsigaridis, K.: A global modeling study on carbonaceous aerosol microphysical characteristics and radiative effects, Atmos. Chem. Phys., 10, 7439-7456, doi:10.5194/acp-10-7439-2010, 2010.

Binkowski, F. and Roselle, S.: Models-3 community multiscale air quality (CMAQ) model aerosol component - 1 . Model description, J. Geophys. Res.-Atmos., 108, 4183, doi:10.1029/2001JD001409, 2003.

Bond, T. C.: Can warming particles enter global climate discussions?, Environ. Res. Lett., 2, 045030, doi:10.1088/17489326/2/4/045030, 2007.

Bond, T. C., Streets, D. G., Yarber, K. F., Nelson, S. M., Woo, J. H., and Klimont, Z.: A technology-based global inventory of black and organic carbon emissions from combustion, J. Geophys. Res.-Atmos., 109, D14203, doi:10.1029/2003JD003697, 2004.

Bond, T. C., Bhardwaj, E., Dong, R., Jogani, R., Jung, S., Roden, C., Streets, D. G., and Trautmann, N. M.: Historical emissions of black and organic carbon aerosol from energy-related combustion, 1850-2000, Global Biogeochem. Cy., 21, GB2018, doi:10.1029/2006GB002840, 2007.

Boucher, O. and Lohmann, U.: The sulfate-CCN-cloud albedo effect - a sensitivity study with 2 general circulation models, Tellus B, 47, 281-300, 1995.

Bouwman, A., Lee, D., Asman, W., Dentener, F., Van Der Hoek, K., and Olivier, J.: A global high-resolution emission inventory for ammonia, Global Biogeochem. Cy., 11, 561-587, 1997.

Chapman, E. G., Gustafson Jr., W. I., Easter, R. C., Barnard, J. C., Ghan, S. J., Pekour, M. S., and Fast, J. D.: Coupling aerosolcloud-radiative processes in the WRF-Chem model: Investigating the radiative impact of elevated point sources, Atmos. Chem. Phys., 9, 945-964, doi:10.5194/acp-9-945-2009, 2009.

Chen, W.-T., Liao, H., and Seinfeld, J. H.: Future climate impacts of direct radiative forcing of anthropogenic aerosols, tropospheric ozone, and long-lived greenhouse gases, J. Geophys. Res.-Atmos., 112, D14209, doi:10.1029/2006JD008051, 2007.

Chen, W.-T., Lee, Y. H., Adams, P. J., Nenes, A., and Seinfeld, J. H.: Will black carbon mitigation dampen aerosol indirect forcing?, Geophys. Res. Lett., 37, L09801, doi:10.1029/2010GL042886, 2010a.

Chen, W.-T., Nenes, A., Liao, H., Adams, P. J., Li, J.-L. F., and Seinfeld, J. H.: Global climate response to anthropogenic aerosol indirect effects: Present day and year 2100, J. Geophys. Res.Atmos., 115, D12207, doi:10.1029/2008JD011619, 2010b.

Chylek, P, Videen, G., Ngo, D., Pinnick, R. G., and Klett, J. D.: Effect of black carbon on the optical properties and climate forcing of sulfate aerosols, J. Geophys. Res., 100, 16325-16332, 1995.

Chin, M. and Jacob, D. J.: Anthropogenic and natural contributions to tropospheric sulfate: A global model analysis, J. Geophys. Res.-Atmos., 101, 18691-18699, 1996.
Chin, M., Rood, R., Lin, S., Muller, J., and Thompson, A.: Atmospheric sulfur cycle simulated in the global model GOCART: Model description and global properties, J. Geophys. Res.-Atmos., 105, 24671-24687, 2000.

Chung, S. and Seinfeld, J.: Global distribution and climate forcing of carbonaceous aerosols, J. Geophys. Res.-Atmos., 107, 4407, doi:10.1029/2001JD001397, 2002.

Corbett, J., Fischbeck, P., and Pandis, S.: Global nitrogen and sulfur inventories for oceangoing ships, J. Geophys. Res.-Atmos., 104, 3457-3470, 1999.

d'Almeida, G., Koepke, P., and Shettle, E.: Atmospheric Aerosols: Global Climatology and Radiative Characteristics, A. Deepak, Hampton, VA, 1991.

Del Genio, A., Yao, M., Kovari, W., and Lo, K.: A prognostic cloud water parameterization for global climate models, J. Climate, 9, 270-304, 1996.

Denman, K. L., Brasseur, G., Chidthaisong, A., Ciais, P., Cox, P. M., Dickenson, R. E., Hauglustaine, D., Heinze, C., Holland, E., Jacob, D., Lohmann, U., Ramachandran, S., da Silva Dias, P. L., Wofsy, S. C., and Zhang, X.: Couplings Between Changes in the Climate System and Biogeochemistry, in: Climate Change 2007: The Physical Science Basis, New York, NY, 2007.

Duncan, B., Martin, R., Staudt, A., Yevich, R., and Logan, J.: Interannual and seasonal variability of biomass burning emissions constrained by satellite observations, J. Geophys. Res.-Atmos., 108, 4100, doi:10.1029/2002JD002378, 2003.

Evans, M. J. and Jacob, D. J.: Impact of new laboratory studies of $\mathrm{N}_{2} \mathrm{O}_{5}$ hydrolysis on global model budgets of tropospheric nitrogen oxides, ozone, and OH, Geophys. Res. Lett., 32, L09813, doi:10.1029/2005GL022469, 2005.

Fiore, A. M., Jacob, D. J., Field, B. D., Streets, D. G., Fernandes, S. D., and Jang, C.: Linking ozone pollution and climate change: The case for controlling methane, Geophys. Res. Lett., 29, 1919, doi:10.1029/2002GL015601, 2002.

Forster, P., Ramaswamy, V., Artaxo, P., Berntsen, T., Betts, R., Fahey, D. W., Haywood, J., Lean, J., Lowe, D. C., Myhre, G., Nganga, J., Prinn, R., Raga, G., Schulz, M., and Van Dorland, R.: Changes in Atmospheric Constituents and in Radiative Forcing, in: Climate Change 2007: The Physical Science Basis, New York, NY, 2007.

Fountoukis, C. and Nenes, A.: Continued development of a cloud droplet formation parameterization for global climate models, J. Geophys. Res.-Atmos., 110, D11212, doi:10.1029/2004JD005591, 2005.

Gettelman, A., Morrison, H., and Ghan, S. J.: A new twomoment bulk stratiform cloud microphysics scheme in the Community Atmosphere Model, Version 3 (CAM3). Part II: Single-column and global results, J. Climate, 21, 3660-3679, doi:10.1175/2008JCLI2116.1, 2008.

Gilliland, A. B., Dennis, R. L., Roselle, S. J., and Pierce, T. E.: Seasonal $\mathrm{NH}_{3}$ emission estimates for the eastern United States based on ammonium wet concentration and an inverse modeling method, J. Geophys. Res.-Atmos., 108, 4477, doi:10.1029/2002JD003063, 2003.

Grieshop, A. P., Reynolds, C. C. O., Kandlikar, M., and Dowlatabadi, H.: A black-carbon mitigation wedge, Nat. Geosci., 2, 533-534, 2009.

Guenther, A., Karl, T., Harley, P., Wiedinmyer, C., Palmer, P. I., and Geron, C.: Estimates of global terrestrial isoprene emissions 
using MEGAN (Model of Emissions of Gases and Aerosols from Nature), Atmos. Chem. Phys., 6, 3181-3210, doi:10.5194/acp-63181-2006, 2006.

Hansen, J., Sato, M., Nazarenko, L., Ruedy, R., Lacis, A., Koch, D., Tegen, I., Hall, T., Shindell, D., Santer, B., Stone, P., Novakov, T., Thomason, L., Wang, R., Wang, Y., Jacob, D., Hollandsworth, S., Bishop, L., Logan, J., Thompson, A., Stolarski, R., Lean, J., Willson, R., Levitus, S., Antonov, J., Rayner, N., Parker, D., and Christy, J.: Climate forcings in Goddard Institute for Space Studies SI2000 simulations, J. Geophys. Res.-Atmos., 107, 4347, doi:10.1029/2001JD001143, 2002.

Heald, C. L., Jacob, D. J., Turquety, S., Hudman, R. C., Weber, R. J., Sullivan, A. P., Peltier, R. E., Atlas, E. L., De Gouw, J. A., Warneke, C., Holloway, J. S., Neuman, J. A., Flocke, F. M., and Seinfeld, J. H.: Concentrations and sources of organic carbon aerosols in the free troposphere over North America, J. Geophys. Res.-Atmos., 111, D23S47, doi:10.1029/2006JD007705, 2006.

Henze, D. K., Seinfeld, J. H., Ng, N. L., Kroll, J. H., Fu, T.-M., Jacob, D. J., and Heald, C. L.: Global modeling of secondary organic aerosol formation from aromatic hydrocarbons: highvs. low-yield pathways, Atmos. Chem. Phys., 8, 2405-2420, doi:10.5194/acp-8-2405-2008, 2008.

Hoose, C., Lohmann, U., Bennartz, R., Croft, B., and Lesins, G.: Global simulations of aerosol processing in clouds, Atmos. Chem. Phys., 8, 6939-6963, doi:10.5194/acp-8-6939-2008, 2008.

Jacob, D.: Heterogeneous chemistry and tropospheric ozone, Atmos. Environ., 34, 2131-2159, 2000.

Jacob, D. J. and Winner, D. A.: Effect of climate change on air quality, Atmos. Environ., 43, 51-63, 2009.

Jacobson, M. Z.: A physically-based treatment of elemental carbon optics: Implications for global direct forcing of aerosols, Geophys. Res. Lett., 27, 217-220, 2000.

Jacobson, M. Z.: Control of fossil-fuel particulate black carbon and organic matter, possibly the most effective method of slowing global warming, J. Geophys. Res.-Atmos., 107, 4410, doi:10.1029/2001JD001376, 2002.

Jones, A., Roberts, D. L., Woodage, M. J., and Johnson, C. E.: Indirect sulphate aerosol forcing in a climate model with an interactive sulphy cycle, J. Geophys. Res., 106, 20293-20310, 2001.

Kanakidou, M., Seinfeld, J. H., Pandis, S. N., Barnes, I., Dentener, F. J., Facchini, M. C., Van Dingenen, R., Ervens, B., Nenes, A., Nielsen, C. J., Swietlicki, E., Putaud, J. P., Balkanski, Y., Fuzzi, S., Horth, J., Moortgat, G. K., Winterhalter, R., Myhre, C. E. L., Tsigaridis, K., Vignati, E., Stephanou, E. G., and Wilson, J.: Organic aerosol and global climate modelling: a review, Atmos. Chem. Phys., 5, 1053-1123, doi:10.5194/acp-5-1053-2005, 2005.

Khairoutdinov, M. and Kogan, Y.: A new cloud physics parameterization in a large-eddy simulation model of marine stratocumulus, Mon. Weather Rev., 128, 229-243, 2000.

Koch, D. and Del Genio, A. D.: Black carbon semi-direct effects on cloud cover: review and synthesis, Atmos. Chem. Phys., 10, 7685-7696, doi:10.5194/acp-10-7685-2010, 2010.

Koch, D., Jacob, D. J., Tegen, I., Rind, D., and Chin, M.: Tropospheric sulfur simulation and sulfate direct radiative forcing in the GISS GCM, J. Geophys. Res., 104, 23799-23822, 1999.

Koch, D., Bond, T. C., Streets, D., Unger, N., and van der Werf, G. R.: Global impacts of aerosols from particular source regions and sectors, J. Geophys. Res.-Atmos., 112, D02205, doi:10.1029/2005JD007024, 2007.

Koch, D., Schulz, M., Kinne, S., McNaughton, C., Spackman, J. R., Balkanski, Y., Bauer, S., Berntsen, T., Bond, T. C., Boucher, O., Chin, M., Clarke, A., De Luca, N., Dentener, F., Diehl, T., Dubovik, O., Easter, R., Fahey, D. W., Feichter, J., Fillmore, D., Freitag, S., Ghan, S., Ginoux, P., Gong, S., Horowitz, L., Iversen, T., Kirkevåg, A., Klimont, Z., Kondo, Y., Krol, M., Liu, X., Miller, R., Montanaro, V., Moteki, N., Myhre, G., Penner, J. E., Perlwitz, J., Pitari, G., Reddy, S., Sahu, L., Sakamoto, H., Schuster, G., Schwarz, J. P., Seland, Ø., Stier, P., Takegawa, N., Takemura, T., Textor, C., van Aardenne, J. A., and Zhao, Y.: Evaluation of black carbon estimations in global aerosol models, Atmos. Chem. Phys., 9, 9001-9026, doi:10.5194/acp-9-9001-2009, 2009.

Koch, D., Bauer, S. E., Del Genio, A. D., Faluvegi, G., McConnell, J. R., Menon, S., Miller, R. L., Rind, D., Ruedy, R., Schmidt, G. A., and Shindell, D.: Coupled aerosol-chemistryclimate twentieth-century transient model investigation: Trends in short-lived species and climate response, J. Climate, 24, 2693 2714, doi:10.1175/2011JCLI3582.1, 2011.

Koepke, P., Hess, M., Schult, I., and Shettle, E. P.: Global Aerosol Data Set, Max-Planck-Institut-fur-Meteorologie, Hamburg, 1997.

Kristjánsson, J. E., Iversen, T., Kirkevag, A., Seland, O., and Debernard, J.: Response of the climate system to aerosol direct and indirect forcing: Role of cloud feedbacks, J. Geophys. Res.Atmos., 110, D24206, doi:10.1029/2005JD006299, 2005.

Leibensperger, E. M., Mickley, L. J., Jacob, D. J., Chen, W. T., Seinfeld, J. H., Nenes, A., Adams, P. J., Rind, D., Streets, D. G., Kumar, N., and Rind, D.: Climatic effects of 1950-2050 changes in US anthropogenic aerosols - Part 2: Climate response, Atmos. Chem. Phys., 12, 3349-3362, doi:10.5194/acp-12-33492012, 2012.

Li, Q., Jacob, D. J., Munger, J. W., Yantosca, R. M., and Parrish, D. D.: Export of $\mathrm{NO}_{y}$ from the North American boundary layer: Reconciling aircraft observations and global model budgets, J. Geophys. Res.-Atmos., 109, D02313, doi:10.1029/2003JD004086, 2004.

Liao, H., Seinfeld, J., Adams, P., and Mickley, L.: Global radiative forcing of coupled tropospheric ozone and aerosols in a unified general circulation model, J. Geophys. Res.-Atmos., 109, D16207, doi:10.1029/2003JD004456, 2004.

Liao, H., Henze, D. K., Seinfeld, J. H., Wu, S., and Mickley, L. J.: Biogenic secondary organic aerosol over the United States: Comparison of climatological simulations with observations, J. Geophys. Res.-Atmos., 112, D06201, doi:10.1029/2006JD007813, 2007.

Liu, H., Jacob, D., Bey, I., and Yantosca, R.: Constraints from Pb210 and $\mathrm{Be}-7$ on wet deposition and transport in a global threedimensional chemical tracer model driven by assimilated meteorological fields, J. Geophys. Res.-Atmos., 106, 12109-12128, 2001.

Lohmann, U. and Feichter, J.: Global indirect aerosol effects: a review, Atmos. Chem. Phys., 5, 715-737, doi:10.5194/acp-5-7152005, 2005.

Lu, Z., Zhang, Q., and Streets, D. G.: Sulfur dioxide and primary carbonaceous aerosol emissions in China and India, 1996-2010, Atmos. Chem. Phys., 11, 9839-9864, doi:10.5194/acp-11-9839- 
2011, 2011.

Malm, W. C., Sisler, J. F., Huffman, D., Eldred, R. A., and Cahill, T. A.: Spatial and seasonal trends in particle concentration and optical extinction in the United States, J. Geophys. Res.-Atmos., 99, 1347-1370, 1994.

Martin, G. M., Johnson, D. W., and Spice, A.: The measurement and parameterization of effective radius of droplets in warm stratocumulus clouds, J. Atmos. Sci., 51, 1823-1842, 1994.

Martin, R., Jacob, D., Yantosca, R., Chin, M., and Ginoux, P.: Global and regional decreases in tropospheric oxidants from photochemical effects of aerosols, J. Geophys. Res.-Atmos., 108, 4097, doi:10.1029/2002JD002622, 2003.

Menon, S., Del Genio, A., Koch, D., and Tselioudis, G.: GCM Simulations of the aerosol indirect effect: Sensitivity to cloud parameterization and aerosol burden, J. Atmos. Sci., 59, 692713, 2002

Meskhidze, N., Sotiropoulou, R. E. P., Nenes, A., Kouatchou, J., Das, B., and Rodriguez, J. M.: Aerosol-cloud interactions in the NASA GMI: model development and indirect forcing assessments, Atmos. Chem. Phys. Discuss., 7, 14295-14330, doi:10.5194/acpd-7-14295-2007, 2007.

Mickley, L. J., Leibensperger, E. M., Jacob, D. J., and Rind, D.: Regional warming from aerosol removal over the United States: Results from a transient 2010-2050 climate simulation, Atmos. Environ., 46, 545-553, doi:10.1016/j.atmosenv.2011.07.030, 2012.

Morales, R. and Nenes, A.: Characteristic updrafts for computing distribution-averaged cloud droplet number, autoconversion rate and effective radius, J. Geophys. Res., 115, D18220, doi:10.1029/2009JD013233, 2010.

Moss, R. H., Edmonds, J. A., Hibbard, K. A., Manning, M. R., Rose, S. K., van Vuuren, D. P., Carter, T. R., Emori, S., Kainuma, M., Kram, T., Meehl, G. A., Mitchell, J. F. B., Nakicenovic, N., Riahi, K., Smith, S. J., Stouffer, R. J., Thomson, A. M., Weyant, J. P., and Wilbanks, T. J.: The next generation of scenarios for climate change research and assessment, Nature, 463, 747-756, doi:10.1038/nature08823, 2010.

Murray, L. T., Jacob, D. J., Logan, J. A., Hudman, R. C., and Koshak, W.: Optimized regional and interannual variability of lightning in a global chemical transport model constrained by LIS/OTD satellite data, J. Geophys. Res.-Atmos., submitted, 2012.

Nakičenovič, N. and Swart, R.: Special Report on Emission Scenarios. A Special Report of the Working Group III of Intergovernmental Panel on Climate Change, in: A Special Report of the Working Group III of Intergovernmental Panel on Climate Change, Cambridge University Press, Cambridge, UK and New York, NY USA, 569, 2000.

National Research Council: Radiative Forcing of Climate Change: Expanding the Concept and Addressing Uncertainties, National Academies Press, Washington, DC, 2005.

Nenes, A. and Seinfeld, J.: Parameterization of cloud droplet formation in global climate models, J. Geophys. Res.-Atmos., 108, 4415, doi:10.1029/2002JD002911, 2003.

Olivier, J. G. J. and Berdowski, J. J. M.: Global emissions sources and sinks, in: The Climate System, edited by: Berdowski, J., Guicherit, R., and Heij, B. J., A. A. Balkema Publishers/Swets and Zeitliner Publishers, Lisse, The Netherlands, 33-78, 2001.

Park, R. J., Jacob, D. J., Chin, M., and Martin, R. V.: Sources of carbonaceous aerosols over the United States and implica- tions for natural visibility, J. Geophys. Res.-Atmos., 108, 4355, doi:10.1029/2002JD003190, 2003.

Park, R. J., Jacob, D. J., Field, B. D., Yantosca, R. M., and Chin, M.: Natural and transboundary pollution influences on sulfate-nitrate-ammonium aerosols in the United States: Implications for policy, J. Geophys. Res.-Atmos., 109, D15204, doi:10.1029/2003JD004473, 2004.

Park, R. J., Jacob, D. J., Kumar, N., and Yantosca, R. M.: Regional visibility statistics in the United States: Natural and transboundary pollution influences, and implications for the Regional Haze Rule, Atmos. Environ., 40, 5405-5423, doi:10.1016/j.atmosenv.2006.04.059, 2006.

Park, R. J., Jacob, D. J., and Logan, J. A.: Fire and biofuel contributions to annual mean aerosol mass concentrations in the United States, Atmos. Environ., 41, 7389-7400, doi:10.1016/j.atmosenv.2007.05.061, 2007.

Penner, J. E., Quaas, J., Storelvmo, T., Takemura, T., Boucher, O., Guo, H., Kirkevåg, A., Kristjánsson, J. E., and Seland, Ø.: Model intercomparison of indirect aerosol effects, Atmos. Chem. Phys., 6, 3391-3405, doi:10.5194/acp-6-3391-2006, 2006.

Penner, J. E., Prather, M. J., Isaksen, I. S. A., Fugelstvedt, J. S., Klimont, Z., and Stevenson, D. S.: Short-lived uncertainty?, Nat. Geosci., 3, 587-588, 2010.

Pierce, J. and Adams, P.: Global evaluation of CCN formation by direct emission of sea salt and growth of ultrafine sea salt, J. Geophys. Res.-Atmos., 111, D06203, doi:10.1029/2005JD006186, 2006.

Price, C. and Rind, D.: A simple lightning parameterization for calculating global lightning distributions, J. Geophys. Res.-Atmos., 97, 9919-9933, 1992.

Pye, H. O. T., Chan, A. W. H., Barkley, M. P., and Seinfeld, J. H.: Global modeling of organic aerosol: the importance of reactive nitrogen $\left(\mathrm{NO}_{\mathrm{x}}\right.$ and $\left.\mathrm{NO}_{3}\right)$, Atmos. Chem. Phys., 10, $11261-$ 11276, doi:10.5194/acp-10-11261-2010, 2010.

Raes, F. and Seinfeld, J. H.: New Directions: Climate change and air pollution abatement: A bumpy road, Atmos. Environ., 43, 5132-5133, doi:10.1016/j.atmosenv.2009.06.001, 2009.

Rayner, N., Parker, D., Horton, E., Folland, C., Alexander, L., Rowell, D., Kent, E., and Kaplan, A.: Global analyses of sea surface temperature, sea ice, and night marine air temperature since the late nineteenth century, J. Geophys. Res.-Atmos., 108, 4407, doi:10.1029/2002JD002670, 2003.

Rind, D., Lerner, J., Jonas, J., and Mclinden, C.: Effects of resolution and model physics on tracer transports in the NASA Goddard Institute for Space Studies general circulation models, J. Geophys. Res.-Atmos., 112, D09315, doi:10.1029/2006JD007476, 2007.

Salzmann, M., Ming, Y., Golaz, J.-C., Ginoux, P. A., Morrison, H., Gettelman, A., Krämer, M., and Donner, L. J.: Two-moment bulk stratiform cloud microphysics in the GFDL AM3 GCM: description, evaluation, and sensitivity tests, Atmos. Chem. Phys., 10, 8037-8064, doi:10.5194/acp-10-8037-2010, 2010.

Sauvage, B., Martin, R. V., van Donkelaar, A., Liu, X., Chance, K., Jaeglé, L., Palmer, P. I., Wu, S., and Fu, T.-M.: Remote sensed and in situ constraints on processes affecting tropical tropospheric ozone, Atmos. Chem. Phys., 7, 815-838, doi:10.5194/acp-7-815-2007, 2007.

Schulz, M., Textor, C., Kinne, S., Balkanski, Y., Bauer, S., Berntsen, T., Berglen, T., Boucher, O., Dentener, F., Guibert, 
S., Isaksen, I. S. A., Iversen, T., Koch, D., Kirkevåg, A., Liu, X., Montanaro, V., Myhre, G., Penner, J. E., Pitari, G., Reddy, S., Seland, Ø., Stier, P., and Takemura, T.: Radiative forcing by aerosols as derived from the AeroCom present-day and pre-industrial simulations, Atmos. Chem. Phys., 6, 5225-5246, doi:10.5194/acp-6-5225-2006, 2006.

Shindell, D. T., Levy, H., Schwarzkopf, M. D., Horowitz, L. W., Lamarque, J.-F., and Faluvegi, G.: Multimodel projections of climate change from short-lived emissions due to human activities, J. Geophys. Res.-Atmos., 113, D11109, doi:10.1029/2007JD009152, 2008.

Shindell, D., Kuylenstierna, J. C. I., Vignati, E., van Dingenen, R., Amann, M., Klimont, Z., Anenberg, S. C., Muller, N., Janssens-Maenhout, G., Raes, F., Schwartz, J., Faluvegi, G., Pozzoli, L, Kupiainen, K., Höglund-Isaksson, L., Emberson, L., Streets, D., Ramanathan, V., Hicks, K., Kim Oanh, N. T., Milly, G., Williams, M., Demkine, V., and Fowler, D.: Simultaneously mitigating near-term climate change and improving human health and food security, Science, 335, 183-189, doi:10.1126/science.1210026, 2012.

Storelvmo, T., Kristjansson, J. E., Ghan, S. J., Kirkevag, A., Seland, O., and Iversen, T.: Predicting cloud droplet number concentration in Community Atmosphere Model (CAM)-Oslo, J. Geophys. Res.-Atmos., 111, D24208, doi:10.1029/2005JD006300, 2006.

Streets, D., Bond, T., Carmichael, G., Fernandes, S., Fu, Q., He, D., Klimont, Z., Nelson, S., Tsai, N., Wang, M., Woo, J., and Yarber, K.: An inventory of gaseous and primary aerosol emissions in Asia in the year 2000, J. Geophys. Res.-Atmos., 108, 8809, doi:10.1029/2002JD003093, 2003.

Streets, D., Bond, T., Lee, T., and Jang, C.: On the future of carbonaceous aerosol emissions, J. Geophys. Res.-Atmos., 109, D24212, doi:10.1029/2004JD004902, 2004.

Toon, O. B., Pollack, J., and KHARE, B.: The optical constants of several atmospheric aerosol species: ammonium sulfate, aluminum oxide, and sodium chloride, J. Geophys. Res., 81, 57335748, 1976.

Twomey, S.: Pollution and the planetary albedo, Atmos. Environ., 8, 1251-1256, 1974.
Unger, N., Bond, T. C., Wang, J. S., Koch, D. M., Menon, S., Shindell, D. T., and Bauer, S.: Attribution of climate forcing to economic sectors, P. Natl. Acad. Sci. USA, 107, 3382-3387, doi:10.1073/pnas.0906548107, 2010.

US Environmental Protection Agency: Acid Rain and Related Programs - 2007 Progress Report, Washington, DC, 2009.

US Environmental Protection Agency: Our Nation's Air - Status and Trends through 2008, Washington, DC, 2010.

van Aardenne, J., Dentener, F., and Olivier, J.: A $1^{\circ} \times 1^{\circ}$ resolution data set of historical anthropogenic trace gas emissions for the period 1890-1990, Global Biogeochem. Cy., 15, 909-928, 2001.

Wang, Y., Jacob, D., and Logan, J.: Global simulation of tropospheric $\mathrm{O}_{3}-\mathrm{NO}_{\mathrm{x}}$-hydrocarbon chemistry 1 . Model formulation, J. Geophys. Res.-Atmos., 103, 10713-10725, 1998.

Wesely, M. L.: Parameterization of surface resistances to gaseous dry deposition in regional scale numerical models, Atmos. Environ., 23, 1293-1304, 1989.

West, J. J., Ansari, A. S., and Pandis, S. N.: Marginal PM2.5: Nonlinear aerosol mass response to sulfate reductions in the Eastern United States, J. Air Waste Manage., 49, 1415-1424, 1999.

Wu, S., Mickley, L. J., Leibensperger, E. M., Jacob, D. J., Rind, D., and Streets, D. G.: Effects of 2000-2050 global change on ozone air quality in the United States, J. Geophys. Res.-Atmos., 113, D06302, doi:10.1029/2007JD008917, 2008.

Yienger, J. and Levy, H.: Empirical model Of global soil-biogenic $\mathrm{NO}_{\mathrm{x}}$ emissions, J. Geophys. Res.-Atmos., 100, 11447-11464, 1995.

Zhang, L., Jacob, D. J., Knipping, E. M., Kumar, N., Munger, J. W., Carouge, C. C., van Donkelaar, A., Wang, Y. X., and Chen, D.: Nitrogen deposition to the United States: distribution, sources, and processes, Atmos. Chem. Phys. Discuss., 12, 241282, doi:10.5194/acpd-12-241-2012, 2012.

Zwiers, F. and von Storch, H.: Taking serial correlation into account in tests of the mean, J. Climate, 8, 336-351, 1995. 